\title{
PENGEMBANGAN BAHAN AJAR MATAKULIAH MENULIS FIKSI BERBASISNILAI-NILAI PENDIDIKAN MULTIKULTURAL PADA PROGRAM STUDI PENDIDIKAN BAHASA DAN SASTRA INDONESIA IKIP BUDI UTOMO MALANG
}

\author{
Susandi \\ Program Studi Pendidikan Bahasa dan Sastra Indonesia \\ IKIP Budi Utomo Malang \\ Jalan Citandui 46 Malang \\ E-mail: susandi.ikipbudiutomo@gmail.com
}

\begin{abstract}
The purpose of this study is to describe: (1) teaching material product; (2) the presentation; (3) the use of language; and (4) graphic writing fiction teaching materials based multicultural values. The design of the teaching materials development in this study was adapted from the theory of design $R \mathcal{E} D$ by Borg and Gall which is carried out through five stages: (1) preliminary study, (2) planning, (3) developing type/shape of the initial product, (4) early stage field trials and revision, (5) primary field trials and revision. Data analysis of this study is obtained percentage score (1) expert literature instructional materials of 98,9\%, (2) proficient writing instructional materials $97.14 \%$,(3) field practitioners in this case teacher of $76.67 \%$, and (4) the students of $85.125 \%$, which means that the percentage of product development is also quite valid/ feasible for learning offiction writing based multicultural values in the education program of language and Indonesian literature IKIP Budi Utomo Malang.
\end{abstract}

Keywords: development, Instructional Materials, listening competence, fiction prose, the values of character education

Menulis adalah proses kreatif memindahkan gagasan ke dalam lambang-lambang tulisan (Semi, 2007: 14). Pandangan lain yang berbeda tentang menulis menyatakan bahwa menulis merupakan kegiatan menggali pikiran dan perasaan tentang sebuah subjek, memilih hal-hal yang akan ditulis, menentukan cara menuliskannya sehingga pembaca dapat memahaminya dengan mudah dan jelas (Mc Crimmon dalam Slamet, 2008:141). Berdasarkan pendapat tersebut dapat disimpulkan bahwa menulis adalah kemampuan memindahkan gagasan ke dalam bentuk lambang-lambang tulisan untuk dapat dipahami dengan mudah dan jelas mutlak diperlukan dalam kehidupan nyata, khususnya mahasiswa program studiPendidikan Bahasa dan Sastra Indonesia.

Fiksi adalah kisahan atau cerita yang diemban oleh pelaku-pelaku tertentu dengan pemeranan, latar serta tahapan dan rangkaian cerita tertentu yang bertolak dari hasil imajinasi pengarangnya sehingga menjalin suatu cerita (Aminuddin, 1987: 66). Karangan fiksi sebagai prosa naratif yang bersifat imajinatif,biasanya masuk akal dan mengandung kebenaran yang mendramatisasikan hubungan-hubungan
antarmanusia(Nurgiyantoro, 2007: 2).Tanpa disengaja, karangan fiksi dapat saja terjadi dalam kehidupan nyata. Seperti kesamaan cerita, tokoh maupun tempat kejadian.Bahkan kadang juga si pengarang lebih sering mengangkat sebuah peristiwa yang benar-benar terjadi dalam kehidupan nyata dengan dilebih-lebihkan agar tampak menarik dan diminati oleh pembaca sebagai bahan apresiasi.Dengan demikian, menulis fiksi adalahkemampuan memindahkan gagasan ke dalam bentuk lambang-lambang tulisan tentang kisahan atau cerita dari sebuah imajinasi tentang tokoh dan penokohan, alur, latar, dan tema sebagai bahan apresiasi.

Arti kata Multikulturalisme berakar dari kebudayaan. Kebudayaan memiliki ragam pengertian. Dalam perspektif kebudayaan, multikulturalisme adalah ideologi yang dapat menjadi alat untuk meningkatkan derajad manusia dan kemanusiaannya (Suparlan, 2002: 1). Multikulturalisme mengakui dan mengagungkan perbedaan dalam kesederajatan secara individual dan kebudayaan (Watson dalam Suparlan, 2002: 1). Pendidikan multikultur adalah pendidikan mengenai keragaman kebudayaan (Andersen dan Cusher, 1994). 
Keragaman kebudayaan yang menjadi sesuatu yang menjadi objek studi yang dipelajari. Dengan kata lain, pengembangan kurikulum haruslah memperhatikan materi pelajaran yang berbasis keragamaan kebudayaan. Yaqin (2005: 25) memahami pendidikan multikultural sebagai strategi pendidikan yang diaplikasikan pada semua jenis mata pelajaran dengan cara menggunakan perbedaan-perbedaan kultural yang ada pada para peserta didik seperti perbedaan etnis, agama, bahasa, gender, klas sosial, ras, kemampuan dan umur agar proses belajar menjadi mudah. Blum (2001: 16) membagi tiga elemen dalam pendidikan multikultural, pertama, menegaskan identitas kultural seseorang, mempelajari dan menilai warisan budaya seseorang. Kedua, menghormati dan berkeinginan untuk memahami serta belajar tentang etnik/kebudayaan-kebudayaan selain kebudayaannya. Ketiga, menilai dan merasa senang dengan perbedaan kebudayaan itu sendiri; yaitu memandang keberadaan dari kelompok-kelompok budaya yang berbeda dalam masyarakat seseorang sebagai kebaikan yang positif untuk dihargai dan dipelihara. Dari bebarapa pengertian tersebut, setidaknya ditemukan tiga kata kunci dalam pendidikan multikultural yaitu (1) proses pengembangan sikap dan perilaku, (2) menghargai perbedaan dan keragaman, dan (3) penghargaan terhadap budaya lain. Kata kunci tersebut akan menjadi landasan dalam merumuskan bahan ajar matakuliah Menulis Fiksi berbasisNilai-Nilai Pendidikan Multikultural pada program studi Pendidikan Bahasa dan Sastra Indonesia IKIP Budi Utomo Malang.

Pendidikan multikultural menurut Gorsky dalam Maksum dan Luluk (2004: 306) mempunyai tujuan dan prinsip sebagai berikut: (a) setiap peserta didik mempunyai kesempatan untuk mengembangkan prestasi mereka; (b) peserta didik belajar bagaimana belajar dan berpikir secara kritis; (c) mendorong peserta didik untuk mengambil peran aktif dalam pendidikan, dengan menghadirkan pengalaman-pengalaman mereka dalam konteks belajar; (d) mengakomodasikan semua gaya belajar peserta didik; (e) mengapresiasi kontribusi dari kelompok-kelompok yang berbeda; (f) mengembangkan sikap positif terhadap kelompok-kelompok yang mempunyai latar belakang yang berbeda; (g) untuk menjadi warga negara yang baik di sekolah maupun di masyarakat; (h) Belajar bagaimana menilai pengetahuan dari perspektif yang berbeda; (i) untuk mengembangkan identitas etnis, nasional dan global; (j) mengembangkan ketrampilanketrampilan mengambil keputusan dan analisis secara kritis sehingga peserta didik dapat membuat pilihan yang lebih baik dalam kehidupan sehari-hari. Adapun prinsip-prinsip pendidikan multikultural yaitu: (a) pemilihan materi pelajaran harus terbuka secara budaya didasarkan pada peserta didik. Keterbukaan ini harus menyatukan opini-opini yang berlawanan dan interprestasi-interprestasi yang berbeda; (b) isi materi pelajaran yang dipilih harus mengandung perbedaan dan persamaan dalam lintas kelompok; (c) materi pelajaran yang dipilih harus sesuai dengan konteks waktu dan tempat; (d) pengajaran semua pelajaran harus menggambarkan dan dibangun berdasarkan pengalaman dan pengetahuan yang dibawa peserta didik ke kelas. (5) Pendidikan hendaknya memuat model belajar mengajar yang interaktif agar supaya mudah dipahami. Dari uraianuraian mengenai pendidikan multikultural tersebut dapatlah dipahami bahwa tujuan pendidikan multikultural ini adalah dimaksudkan untuk menciptakan kehidupan yang harmonis dalam masyarakat yang serba majemuk.

Berdasarkan wawancara dengan tiga orang dosen Pendidikan Bahasa dan Sastra Indonesia yang membina matakuliah Menulis Fiksi, ditemukan bahwa bahan ajarmenulis fiksi berbasis multikultural belum pernah digunakan di kelas secara khusus.Dosen beranggapan bahwa bahan ajar menulis fiksiberbasis multikultural sangat jarang ditemukan di toko buku. Dosen juga masih belum terlatih dan terbiasa membuat bahan ajar berbasis multikultural karena keterbatasan pengetahuan tentang budaya. Pembelajaran menulis fiksi yang dilakukan selama ini juga monoton dikarenakan bahan ajar menulis fiksi berbasis multikultural masih sangat minim.Alhasil, bahan ajar menulis fiksi yang diajarkan oleh dosen di kelas masih dengan metode konvensional seperti ceramah atau tanya jawab. Pembelajaran menulis fiksi masih sebatas pengetahuan tentang menulis fiksi, belum sampai kepada peningkatan 
kemampuan menulis lewat media fiksi seperti novel atau cerpen.

Badan Standar Nasional Pendidikan (2006: 10) menjelaskan bahwa kegiatan pembelajaran harus dapat mendukung tumbuh kembangnya pribadi peserta didik yang berjiwa kewirausahaan dan mempunyai kecakapan hidup. Hal ini berarti bahwa pembelajaran harus bermakna bagi peserta didik. Pembelajaran harus sebagai upaya pendidik dalam memberikan bekal bagi peserta didik untuk menjalani kehidupannya sehari-hari, khususnya pembelajaran menulis fiksi.

Uraian tersebut menunjukkan bahwa ada kesenjangan antara kebutuhan mahasiswa untuk memiliki kemampuan menulis yang efektif dengan fasilitas bahan ajarmenulis fiksi oleh dosen. Kesenjangan tersebut menimbulkan masalah bagi pembelajaran menulis fiksi. Pembelajaran menulis fiksi yang dilakukan oleh dosen belum mampu menarik minat dan membangkitkan motivasi mahasiswa, sehingga keefektifan pembelajaran dan hasil belajar menulis fiksi masih belum meningkat. Oleh karena itu, pengembangan bahan ajar menulis fiksi yang sesuai dengan Badan Standar Nasional Pendidikan dan Sistem Pendidikan Nasional sangat diperlukan.

Pendidikan multikultural akan menjadi menarik apabila diintegrasikan ke dalam bahan ajar matakuliah Menulis Fiksi. Karya fiksi yang dihasilkan dinilai bisa menjadi medium yang strategis untuk mewujudkan tujuan itu. Melalui karya fiksi, mahasiswa bisa melakukan olah rasa, olah batin, dan olah budi secara intens sehingga secara tidak langsung mahasiswa memiliki perilaku dan kebiasaan positif melalui proses apresiasi dan berkreasi. Karya fiksi juga mampu memberikan dasar pengetahuan tentang nilainilai pendidikan multikultural.

Salah satu langkah implementasi nilai-nilai pendidikan multikultural dalam bahan ajar dapat dilakukan dengan membuat konstruk keilmuan berbasis multikultural. Konstruk keilmuan dalam proses pendidikan dapat diaktualisasikan melalui struktur kurikulum yang memuat nilai-nilai pendidikan multikultural. Dalam konteks dimensi tersebut, pengembangan nilai-nilai multikultural matakuliah Menulis Fiksi di program studi Bahasa dan Sastra Indonesia IKIP Budi Utomo
Malang merupakan pengembangan dari nilainilai Kebudiutamaan yang telah menjadi landasan bagi para civitas di lingkungan IKIP Budi Utomo Malang yaitu: keindonesiaan, kepatutan, kepatuhan, kemanfaatan dan kepedulian. Nilai-nilai tersebut kemudian dikembangkan sebagai dasar pengembangan bahan ajar matakuliah Menulis Fiksi berbasis Multikulturalismeyang selanjutnya didukung kulturKebudiutamaan yang adaptif dan responsif terhadap pendidikan multikultural. Kultur Kebudiutamaan turut membentuk sikap dosen dan mahasiswa serta karyawan terhadap penerapan pendidikan multikultural. Adapun nilai-nilai pendidikan multikultural yang terimplementasi pada bahan ajarmatakuliah Menulis Fiksi sebagai berikut:

\section{(1) Persamaan Hak}

Hal ini menjadi penting karena latar belakang mahasiswa IKIP Budi Utomo Malang mayoritas berasal dari daerah diluar Jawa. Pola pergaulan yang sangat majemuk membawa potensi terjadinya konflik namun pengembangan sikap menghormati perbedaan dapat meminimalisasi potensi konflik.

\section{(2) Toleransi}

Internalisasi sikap menghormati dan mengakui persamaan hak akan mengarah pada pembentukan sikap toleransi. Toleransi menjadi penting dalam kehidupan multikultural.

(3) Keadilan

Sikap toleransi dapat membentuk perilaku adil. Prinsip adil sebagai pilar pendidikan multikultural. Keadilan dalam proses pendidikan termasuk didalamnya mahasiswa mendapatkan kesempatan yang sama untuk memperoleh transformasi ilmu maupun keadilan dalam memberikan kesempatan yang sama walaupun latar belakang berbeda.

\section{(4) Persaudaran}

Persaudaraan menghimpun seluruh prinsip kemanusiaan. Manusia menyatu dengan yang lain dalam hubungan keluarga kemudian hubungan umat dan akhirnya hubungan kemanusiaan.

\section{(5) Etika Pergaulan}

Kemajuan peradaban dan globalisasi serta modernisasi membawa perubahan struktur masyarakat. Arus globalisasi memungkinkan terjadinya akses informasi termasuk budaya, aliran, ide, gagasan semakin mudah sehingga 
akulturasi budaya dapat terjadi dan sebaliknya dapat memunculkan konflik sosial. Modernisasi dan globalisasi menjadikan pergaulan dalam kehidupan multikultural membutuhkan pemahaman mahasiswa pada etika pergaulan.

Bahan ajar matakuliah Menulis Fiksi berbasis nilai-nilai pendidikan multikultural dikembangkan dengan berbagai pendekatan yang dianggap sesuai dan dibutuhkan dalam mengembangkan nilai-nilai di atas. Salah satunya dengan menggunakan model pembelajaran berbasis masalah. Model pembelajaran berbasis masalah dipandang sesuai, sebab model pembelajaran ini menggunakan masalah dunia nyata sebagai suatu konteks bagi mahasiswa untuk belajar tentang cara berfikir kritis dan keterampilan pemecahan masalah, serta untuk memperoleh pengetahuan dan konsep yang esensial dari materi pelajaran.

Implementasi PBL dirancang dengan struktur pembelajaran (1) peserta didik secara individual maupun kelompok dihadapkan pada suatu masalah yang kontekstual, (2) masalah yang dikonfrontasikan diusahakan sedekat mungkin dengan kehidupan peserta didik sehari-hari, (3) fasilitator menyiapkan materi pelajaran yang dapat menuntut peserta didik kearah pemecahan masalah, (4) memberikan tanggung jawab kepada peserta didik untuk mengarahkan sendiri pembelajarannya, (5) membentuk kelompok-kelompok kecil dalam pembelajaran, (6) menuntut agar peserta didik menampilkan apa yang telah dipelajari (Savoi dan Hughes, 1994).

Pengembangan bahan ajar ini bertujuan untuk menghasilkan bahan ajar matakuliah Menulis Fiksi berbasis nilai-nilai pendidikan multikulturaldilihat dari aspek kelayakan (1) isi, (2) penyajian, (3) bahasa, dan (4) grafika. Bahan ajar ini akan dikemas dalam bentuk buku ajar. Hal ini mengacu kepada pendapat Prastowo (2011: 17) bahwa bahan ajar terbagi atas buku pelajaran, modul, handout, LKS, model atau maket, bahan ajar audio, bahan ajar interaktif, dan sebagainya.

\section{METODE}

Penelitian ini adalah Research and Development (penelitian dan pengembangan) yang merujuk pada teori Borg \& Gall.Menurut
Borg dan Gall (1989: 783-795), pendekatan Reseach and Development ( $\mathrm{R} \& \mathrm{D})$ dalam pendidikan meliputi sepuluh langkah, yaitu (1) studi pendahuluan, (2) perencana-an, (3) mengembangkan jenis/bentuk produk awal, (4) uji coba lapangan tahap awal, (5) revisi terhadap produk utama, (6) uji coba lapangan utama, (7) revisi terhadap produk operasional, (8) uji lapangan operasional, (9) revisi terhadap produk akhir, dan (10) Mendesiminasikan dan mengimplementasikan produk.

Namun, pengembangan produk yang dilaksanakan pada penelitian ini dilaksanakan dalam lima tahap sampai menghasilkan produk akhir, yaitu bahan ajar matakuliah Menulis Fiksi Berbasis Nilai-Nilai Pendidikan Multikultural yang dikemas dalam bentuk buku pelajaran,sehingga tidak sampai pada tahap diseminasi dan implementasi produk. Untuk sampai pada tahap diseminasi dan implementasi produk dapat dilakukan penelitian lanjutan.Tahapan penelitianini adalah (1) melakukan studi pendahuluan, (2) melakukan perencanaan, (3) mengembangkan jenis/bentuk produk awal, (4) melakukan uji coba lapangan tahap awal dan revisi, (5) melakukan uji coba lapangan utama dan revisi.

Agar uji coba produk tercapai dengan baik, perlu ketepatan dalam pemilihan desain uji coba, subjek uji coba, jenis data, instrumen pengumpulan data, serta teknis analisis data.Uji coba produk dilakukan terhadap ahli materi pembelajaran menulis fiksi, ahli penulisan bahan ajar, dosen matakuliah Menulis Fiksi, dan mahasiswa.Penelitian ini dilakukan di program studi Pendidikan Bahasa dan Sastra Indonesia, Fakultas Pendidikan Ilmu Sosial dan Humaniora IKIP Budi Utomo Malang.

Jenis data dalam penelitian ini adalah data kualitatif dan kuantitatif.Data kualitatif diperoleh dari (1) wawancara mahasiswa, (2) wawancara dosenmatakuliah Menulis Fiksi, dan (3) analisis buku teks. Data kualitatifberikutnya diperoleh dari saran dan catatan dari (1) ahli materi pembelajaran menulis fiksi, (2) ahli penulisan bahan ajar, (3) dosenmatakuliah Menulis Fiksi, dan (4) mahasiswa. Sedangkan data kuantitatif diperoleh dari angket terhadap (1) ahli materi pembelajaran menulis fiksi, (2) ahli penulisan bahan ajar, (3) dosenmatakuliah Menulis Fiksi, dan (3) mahasiswa. 
Pengumpulan data dalam penelitian menggunakan dua instrumen, yaitu instrumen utama dan instrumen penunjang. Instrumen utama dalam penelitian ini adalah peneliti sendiri, sedangkan instrumen penunjang berupa angket atau kuesioner dan wawancara bebas. Instrumen penunjang digunakan untuk menghimpun data (1) ahli materi pembelajaran menulis fiksi, (2) ahli penulisan bahan ajar, (3) dosen matakuliah Menulis Fiksi, dan (4) mahasiswa. Pertama, Instrumen angket terdiri dari angket oleh ahli pembelajaran menulis fiksi, ahli pendidikan multikultural, ahli penulisan bahan ajar, dosen matakuliah Menulis Fiksi, dan mahasiswa. Kedua, wawancara digunakan untuk mengklarifikasi secara lisan saran-saran tertulis yang belum jelas bagi peneliti. Klarifikasi dimaksudkan untuk menggali pendapat ahli terhadap bahan ajar yang dikembangkan. Komentar dan saran untuk kesalahan yang sama yang terdapat pada buku pelajaran disampaikan sekaligus dan berlaku untuk perbaikan bahan ajar secara menyeluruh.

Teknik analisis data yang digunakan adalah teknik analisis data kuantitatif dengan menghitung presentasi jawaban tiap item pertanyaan. Data kuantitatif berupa data tidak terstruktur (data verbal) yang digunakan setelah diseleksi sesuai kebutuhan. Teknik analisis data kuantitatif dilakukan dengan menggunakan dua rumus yaitu (1) rumus untuk mengolah data per item

$\mathrm{P}=\frac{x}{x i} x 100 \%$

\section{Keterangan:}

$\mathrm{P} \quad$ : persentase

X : jawaban responden dalam satu item

$\mathrm{Xi}$ : nilai ideal dalam satu item

$100 \%$ : konstanta

b. rumus untuk mengolah data secara keseluruhan item

$$
P=\frac{\sum x}{\sum x i} X 100 \%
$$

Keterangan :

Sigma $x \quad$ : jumlah keseluruhan jawaban responden dalam seluruh item

Sigma Xi : jumlah keseluruhan skor ideal dalam satu item

$100 \% \quad$ : konstanta

\section{Tabel Perhitungan Analisis Data}

(Sugiyono, 2008: 417\% 421)

\section{HASIL DAN PEMBAHASAN}

Penelitian dan pengembangan ini menghasilkan produk bahan ajar.Bahan ajar tersebut berupa buku ajar Menulis FiksiBerbasis Nilai-Nilai Pendidikan Multikultural.Perbedaan hasil pengembangan produk bahan ajar ini dengan bahan ajar sejenis terletak pada pemanfaatan contoh-contoh teks cerita fiksi yang beragam yang berasal dari beberapa daerah Indonesia yang mampu menunjukkan nilai-nilai pendidikan multikultural dalam kehidupan masyarakat Indonesia. Beberapa bagian naskah yang telah dipilih tersebut kemudian diubah ke dalam bentuk contoh pengembangan tema, amanat, alur, latar, tokoh dan penokohan, sudut pandang, gaya bahasa, dan gaya penceritaan, Pemilihan naskah-naskah tersebut didasarkan pada kebutuhan tentang pengetahuan, sikap, dan tindakan dalam nilai-nilai pendidikan multikultural yang akan diintegrasikan dalam produk bahan ajar ini. Nilai-nilai pendidikan multikultural tersebut mencakup nilai persamaan hak, toleransi, keadilan, persaudaraan, dan etika pergaulan.

Bahan ajar yang disusun telah disesuaikan dengan kurikulum yang berlaku di IKIP Budi Utomo Malang yaitu mengacu pada kurikulum KKNI. Bahan ajar ini berpedoman pada Satuan Acara Perkuliahan (SAP) serta Rencana Pelaksanaan Pembelajaran (RPP) yang telah disesuaikan dengan kurikulum KKNI. Bahan ajar ini adalah bahan ajar yang berbasis teks.

Materi yang dikembangkan pada produk bahan aiar Menulis FiksiBerbasis Nilai-Nilai

\begin{tabular}{|c|c|c|c|}
\hline \multicolumn{3}{|c|}{ Hasil Uji } & Kriteria \\
\hline Kategori & Persentase & Kualifikasi & $\begin{array}{c}\text { Kalidasi } \\
\text { Valid } \\
\text { (tidak } \\
\text { perlu } \\
\text { revisi) }\end{array}$ \\
\hline 4 & $\begin{array}{c}86 \%- \\
100 \%\end{array}$ & $\begin{array}{c}\text { Sangat } \\
\text { Layak }\end{array}$ & $\begin{array}{c}\text { Cukup } \\
\text { Valid } \\
\text { (tidak } \\
\text { perlu } \\
\text { revisi) }\end{array}$ \\
\hline 3 & $76 \%-85 \%$ & Layak & $\begin{array}{c}\text { Kurang } \\
\text { Valid } \\
\text { (Revisi) }\end{array}$ \\
\hline 2 & $56 \%-75 \%$ & $\begin{array}{c}\text { Cukup } \\
\text { Layak }\end{array}$ & $\begin{array}{c}\text { Tidak } \\
\text { Valid } \\
\text { (Revisi) }\end{array}$ \\
\hline 1 & $<55 \%$ & Lurang \\
\hline
\end{tabular}


Pendidikan Multikulturaladalah (1) memulai cerita, (2) menemukan dan mengembangkan tema, (2) mengembangkan amanat cerita, (3) mengembangkan alur, (4) mengembangkan latar, (5) membuat kerangka cerita, (6) mengembangkan tokoh dan penokohan, (7) mengembangkan dialog, (8) mengembangkan sudut pandang, (9) mengembangkan gaya bahasa dan penceritaan, (10) mengakhiri cerita. Buku ajar ini diberi judul Menulis FiksiBerbasis Nilai-Nilai Pendidikan Multikultural. Jenis materi yang dikembangkan dalam buku ajar ini menitikberatkan pada aspek sikap atau nilai.

Berikutnya, pemilihan strategi yang digunakan dalam buku ajar. Strategi yang dikembangkan menggunakan model pembelajaran berbasis masalah. Pada masingmasing kegiatan, buku pelajaran dibagi lagi menjadi tiga bagian, yaitu teori, contoh, dan penugasan. Buku ajar Menulis FiksBerbasis NilaiNilai Pendidikan Multikulturaldalam penelitian ini mengalami beberapa revisi berdasarkan data yang diperoleh dari ahli, praktisi, dan mahasiswa dengan harapan buku ini dapat menjadi panduan bagi dosen dan mahasiswa dalam matakuliah Menulis Fiksi.

Pengembangan bahan ajar ini divalidasikan kepada ahli materi pembelajaran sastra, ahli penulisan bahan ajar, dan praktisi lapangan yakni seorang dosen matakuliah Menulis Fiksi dari lembaga tempat penelitian. Hasil validasi dari semua ahli menunjukkan bahwa pengembangan bahan ajar Menulis FiksiBerbasis Nilai-Nilai Pendidikan Multikulturalini valid/ layak untuk digunakan di program studi Pendidikan Bahasa dan Sastra IKIP Budi Utomo Malang. Hal ini dibuktikan dengan hasil validasi dari ahli dan angket yang diberikan kepada mahasiswa.

Hasil analisis data dari angket ahli materi pembelajaran sastra diperoleh skor persentase sebesar 98,9\%, dan ahli penulisan bahan ajar diperoleh skor persentase sebesar $97,14 \%$, yang artinya produk pengembangan valid/sangat layak untuk digunakan. Analisis data dari praktisi lapangan dalam hal ini dosen matakuliah Menulis Fiksi diperoleh skor persentase $76,67 \%$, yang artinya produk pengembangan cukup valid/layak untuk digunakan. Adapun hasil uji coba lapangan terhadap mahasiswa diperoleh skor persentase
$85,125 \%$ yang artinya produk pengembangan juga cukup valid/layak untuk digunakan.

\section{KESIMPULAN}

Berdasarkan penjelasan tersebut dapat disimpulkan bahwa produk pengembangan bahan ajar Menulis Fiksi Berbasis Nilai-Nilai Pendidikan Multikulturalvalid dan efektif serta layak untuk digunakan dan diharapkan dapat meningkatkan prestasi belajar mahasiswa.Dari segi kepraktisan, bahan ajar ini telah dinilai praktis.Hal ini disebabkan bahan ajar ini memenuhi indikator dari validator yang telah menyatakan bahwa bahan ajar yang dikembangkan layak digunakan.

Sebagai saran pemanfaatan produk hasil pengembangan, dosen matakuliah Menulis Fiksi dan mahasiswa disarankan menggunakan bahan ajar ini dalam matakuliah Menulis Fiksi. Selanjutnya, produk pengembangan ini dapat disebarluaskan di semua kelas di program studi Pendidikan Bahasa dan Sastra Indonesia yang bersangkutan atau bahkan di dalam asosiasi program studi Pendidikan Bahasa dan Sastra Indonesia. Produk bahan ajar ini juga dapat dikembangkan lebih lanjut menjadi produk media pembelajaran interaktif, sehingga pembelajaran Menulis Fiksi menjadi lebih menarik.

\section{DAFTAR RUJUKAN}

Aminuddin. 1987. Pengantar Apresiasi Sastra. Bandung: Sinar Baru Algesindo Offset.

Borg, W. R., \& Gall, M. D. 1989. Educational Research. New York: Longman.

Prastowo, A. 2011. Panduan Kreatif Membut Bahan Ajar Inovatif. Jokjakarta: DIVA Press.

Savoie J.M. \& Hughes A.S. 1994. Problem-Based Learning As Classroom Solutions. Educational Leadership, 3:54-57.

Sugiyono. 2008. Metode Penelitian Pendidikan: Pendekatan Kuantitatif, Kualitatif, dan RED. Bandung: Penerbit Alfabeta.

Nurgiyantoro, B. 2007. Teori Pengkajian Fiksi.

Yogyakarta: Gajah Mada University Press.

Slamet, St.Y. 2007. Dasar-Dasar Keterampilan

Berbahasa Indonesia. Surakarta: Universitas

Sebelas Maret Press.

Semi, M. A. 2007. Menulis Efektif. Padang:

Angkasa Raya. 
Suparlan, P. “Menuju Masyarakat Indonesia yang Multikultural," Makalah.

Disampaikan pada Simposium

Internasional Bali ke-3, Jurnal Antropologi Indonesia, Denpasar Bali, 16-21 Juli 2002.

Yaqin, M. A.. 2005. Pendidikan Multikultural:

Cross-Cultural Understanding untuk

Demokrasi dan Keadilan.Yogyakarta: Pilar Media.

Blum, A. L. 2001. Etika Terapan: Sebuah Pendekatan Multikultural.Diterjemahkan oleh: Sinta Carolina dan Dadang Rusbiantoro. Yogyakarta: Tiara Wacana.

Maksum, A. dan Ruhendi,,L Y. 2004.Paradigma pendidikan Universal di Era Modern dan PostModernisme. Jogyakarta: IRCiSod.

Badan Standar Nasional Pendidikan. 2006.

Panduan Penyusunan Kurikulum Tingkat Satuan Pendidikan Jenjang Pendidikan Dasar dan Menengah. Jakarta: BSNP. 
8\| Susandi, Pengembangan Bahan Ajar Mata Kuliah .... 


\title{
THE EFFECTIVENESS OF CLUSTERING AND FREEWRITING AS PREWRITING ACTIVITY FOR STUDENT'S WRITING ABILITY IN IKIP BUDI UTOMO MALANG
}

\author{
Ike Dian Puspitasari \\ Program Studi Pendidikan Bahasa Inggris \\ IKIP Budi Utomo Malang \\ Jalan Citandui 46 Malang \\ ikedianpuspitasari@budiutomomalang.ac.id
}

\begin{abstract}
Writing is productive skill which demands students to think logically. In this research, the researcher used two groups consisting Group A (20 students) who was given clustering as prewriting activity, and Group B (20 students) who was given freewriting as their prewriting activity. The result shows that clustering which was used by Group A did not show significant effect toward students' writing ability. While, freewriting which is used in Group B shows significant effect towards students' writing ability. The two different results found might be caused by grammatical and vocabulary items scores in students writing draft.
\end{abstract}

Writing force students' logical thinking to delivering their idea as written product. It does not only demand English fluency, but also English accuracy. In transforming knowledge, writing instruction increase role in foreign language education as writing effectively (Weigle, 2002).

Richards and Renanadya (2002) assumes that writing is one of highest skill for EFL because it demands to generate and organize idea, and also transfer it become a good paragraph or essay. Hence, the way to transfer the ideas also consider the vocabulary items used, mechanics, and grammatical.

In order to arrange the ideas into a good paragraph or essay, students do prewriting activity. "The term "pre-writing" has two different meanings. It can mean the stage before children learn writing, which is referred to as hand skills. The other meaning, which is the concern of this article, points to the first stage of the writing process, followed by drafting, revision, editing and publishing" (Mogahed, 2013).Zheng and Dai (2012) adds that "the prewriting activities generate ideas which can encourage a free flow of thoughts and help students discover both what they want to say and how to say it on paper".

Brown (2007) mentions some prewriting activities, such as clustering, freewriting, brainstorming, reading, and so on. Mogahed (2013) states that prewriting activity is the basic stage done in writing before continue to next stages such as drafting and revising, while it also encourages students to write.

Mahnam and Nejadansari (2012) applied concept mapping in their research. They used 2 groups consist 11 and 12 participants. The experimental group was given mind mapping which is similar to clustering, reading relevant texts, and negotiation. The result shows that the prewriting is significant.

In this research, the researcher tries to apply clustering and freewriting as prewriting activity to be used as prewriting activity. Pretest and post test will be given for those two groups.Based on the background above, the statements of problem are as follows:

1. How is the effect of clustering applied as prewriting activity for students' writing ability in IKIP Budi Utomo Malang?

2. How is the effect of freewriting applied as prewriting activity for students' writing ability in IKIP Budi Utomo Malang?

\section{METHOD}

This research used quasi experimental as research design. The researcher used three groups consisting 20 students for each group. Group A as Experimental Group 1 that was given clustering, and Group B as Experimental Group 2 that was given freewriting. Each groups was given same topic for pretest and posttest. Each group also got same material or explanation. The research was done in 5 meetings for each group. Pretest was given in Meeting 1. Students wrote 
their idea regarding to certain topics in 100 minutes. In meeting 2, teacher explained material (descriptive text) and asked them to prepare their ideas in the form of clustering or freewriting (experimental groups). Then, they develop their ideas into a good descriptive text based on their draft in Meeting 3. In meeting 4, they revise their first writing draft by considering teacher's feedback. Hence, they wrote their final writing product in Meeting 5.

\section{FINDING}

Posttest was given for Group A, Group B in Meeting 5. The first step, researcher analyze the normality of three groups. Here the result of normality test done by researcher:

Table 3.1 Normality Test

\begin{tabular}{|l|l|r|}
\hline \multicolumn{2}{|l|}{} & \multicolumn{1}{|c|}{$\begin{array}{c}\text { Unstandardize } \\
\mathrm{d} \text { Residual }\end{array}$} \\
\hline $\mathrm{N}$ & \multicolumn{2}{|l|}{20} \\
\hline Normal Parameters & $\mathrm{a}$ \\
& Mean & .0000000 \\
\cline { 2 - 3 } & Std. Deviation & 4.32426678 \\
\hline $\begin{array}{l}\text { Most Extreme } \\
\text { Differences }\end{array}$ & Absolute & .112 \\
\cline { 2 - 3 } & Positive & .112 \\
\cline { 2 - 3 } & Negative & .085 \\
\hline Kolmogorov-Smirnov Z & & .962 \\
\hline Asymp. Sig. (2-tailed) & \\
\hline \multicolumn{2}{|l|}{ a. Test distribution is Normal. } & \\
\hline
\end{tabular}

From the Table 3.1, the significant value is 0.962 which is bigger than á $=0.05$. Hence, it can be concluded that the data is normal. Hence, the homogeneity was also analyzed by using SPSS. Here the result of homogeneity test.

Table 3.2 Test of Homogeneity of Variances

\begin{tabular}{|l|r|r|r|r|}
\hline & $\begin{array}{c}\text { Levene } \\
\text { Statistic }\end{array}$ & df1 & \multicolumn{1}{c|}{ df2 } & \multicolumn{1}{c|}{ Sig. } \\
\hline Group A & 10.252 & 4 & 15 & .000 \\
\hline Group B & 1.383 & 4 & 15 & .287 \\
\hline
\end{tabular}

While the significant value $(0.287)$ is also bigger than á $=0.05$, it can be concluded that the data is homogeny. After finding the normality value and homogeneity value, the researcher continue to analyze whether clustering and freewriting significant or not. Here the result of data analysis:

Table 3.3 ANOVA

\begin{tabular}{|l|l|r|r|r|r|r|}
\hline & & $\begin{array}{c}\text { Sum of } \\
\text { Squares }\end{array}$ & df & Mean Square & F & \multicolumn{1}{c|}{ Sig. } \\
\hline \multirow{3}{*}{ Group A } & Between Groups & 49.286 & 4 & 12.321 & .520 & .723 \\
\cline { 2 - 7 } & Within Groups & 355.714 & 15 & 23.714 & & \\
\cline { 2 - 7 } & Total & 405.000 & 19 & & & \\
\hline \multirow{3}{*}{ Group B } & Between Groups & 517.560 & 4 & 129.390 & 4.076 & .020 \\
\cline { 2 - 7 } & Within Groups & 476.190 & 15 & 31.746 & & \\
\cline { 2 - 7 } & Total & 993.750 & 19 & & & \\
\hline
\end{tabular}


Group A was given clustering as students' prewriting activity. Group A showed that significant value 0.723 in df 19 (N-1) which is bigger than á $=0.05$. Hence, $\mathrm{Ha}_{1}$ is rejected. There is no significant effect between clustering as prewriting activity and students' writing ability. For another group, Group B was given Freewriting as students' prewriting activity. from Group B, it can be seen that the significant value is 0.020 . It is bigger than á=0.05. Thus, $\mathrm{Ha}_{2}$ is accepted. For Group B, it can be concluded that there is significant effect between freewriting and students' writing ability.

\section{DISCUSSION}

The result showed that clustering was not significant towards students' writing ability. However, the second prewriting activity (freewriting) showed significant effect towards students' writing ability. The first result differs to Mogahed (2013) who found that mind mapping that is similar to clustering showed significant effect towards students' writing ability. From the teacher's feedback, the low scores from four aspect (content, grammatical error, vocabulary items, and mechanics) were in grammatical error and vocabulary items. Compared with Group B that was given freewriting, grammatical error and vocabulary items have better score than Group A. It might be influenced by the first draft (clustering and freewriting). In clustering, students only write down their ideas in some keywords. However, the freewriting contains more vocabulary items and also consider grammatical error. Hence, it influence their next draft and their score of final writing.

\section{CONCLUSION AND SUGGESTION}

The data analysis of Group A shows that there is no significant effect between clustering as prewriting activity and students' writing ability. However, the second result of Group B shows that there is significant effect between freewriting as prewriting ability and students' writing ability. Both groups are normal and homogeny. It means that there is not any different ability from one student to other students' within group and between group.

For next research, it may be better if the variable is controlled. For instance, the control of gender, age, and their English proficiency. Therefore, it can be found whether the prewriting ability applied is significant or not by considering those controlled variables.

\section{ACKNOWLEDGEMENT}

This research was done by Ike Dian Puspitasari, MPd in 2017. The writing class in IKIP Budi Utomo Malang was used in conducting the research. All gratitude was given for all people who participate to help conducting this research.

\section{REFERENCE}

Brown, H.D.2007.Principles of Language Teaching and Learning. New York: Pearson Education Inc.

Mahnam, L., \&Nejadansari, D. 2012. The Effect of Different Pre-Writing Strategies on Iranian EFL Writing Achievement. International Education Strategies Vol. 5 No. 1 (www.csenet.org/ies)

Mogahed, M. M. 2013. Planning Out PreWriting Activities. International Journal of English and Literature Vol 4 (3) pp. 60-88 (www.academicjournals.org/IJEL) 
12\| Ike Dian, The Effectiveness Of Clustering ..... 


\title{
ANALISIS PERSEPSI MASYARAKAT TERHADAP KOMUNITAS PEDULI LUBANG JALANAN KOTA MALANG
}

\author{
Faizal Kurniawan \\ IKIP Budi Utomo Malang \\ faizalkurniamsi@gmail.com
}

\begin{abstract}
AAbstract: Malang City with all its facilities is ancrowded city. As a result the streets in most areas in Malang Raya is becoming frequently used. The density of vehicle volume every day resulted in many holes in the road. However, late handling of the municipal and district governments resulted in more and more potholes in the streets. Of course this results in disappointment for road users. Many victims of accidents caused by falling due to potholes. Not least the victims of this perforated road encourage a group of young people to form a Community Care for the Hole of the Road. This group moves voluntarily. Social counciosness encourages them to form this community. In the action, they make a circular sign or edge with a white pylox against the holes on each road segment. The goal is white as a sign for road users to see the white marka they have created. The sign is felt quite effective because in the distance before the hole, the rider can lower the speed. A lot of appreciation is given to this community. Because by remembering the many holes in the streets of Malang, and the number of "Personal Capital" they have spent for this social action. Their action also received a response from the mayor. This study uses a case study approach and indepth interview method to community members and also a source of road users who recognize the existence of this grassroots community. Observations are made to this community by following all the activities of this group. As a result, people's perception of the two groups is divided into two, the pros and cons of their actions. In the contrary reasoned that the existence of sentences that are not appropriate to be displayed in public facilities. In conclusion, the pro-society perception towards grassroots movements can be a resistance movement for government policies that are slow to deal with this problem. Evidenced by the more intense they carry out the action, the response of the city government and Malang district faster. It is expected that this social awareness will encourage Malang city and district government to be more sensitive to the sound of netizens in both social media and aspirations directly.
\end{abstract}

Keywords: Perception, Mass Communication, Road Community Care

Kota Malang Raya adalah salah satu kota dengan aktivitas yang padat. Hal itu dibuktikan dengan adanya tiga perguruan tinggi, dan 51 perguruan tinggi swasta. Selain itu, banyak tersedianya industri swasta dan badan usaha milik negara di Kota yang berjuluk kota bunga dan kota pendidikan ini. Aktivitas di Malang Raya tentu tidak akan pernah sepi. Selain itu letak geografis kota Malang yang menjadi penghubung antara Surabaya - Sidoarjo - Blitar - Kediri menjadikan Malang Raya menjadi destinasi bagi infestor-infestor yang ingin mengembangkan usahanya.Dalam situs resminya mengatakan,bagian selatan merupakan dataran tinggi yang sering digunakan untuk kawasan industri.Sedangkan bagian utara Malang Raya merupakan dataran tinggi yang subur, sehingga pertanian dan pariwisata Malang Raya terpusat di daerah utara.Sedangkan bagian timur merupakan kawasan perumahan yang padat akan penduduk. Bagian barat Malang Raya adalah kawasan pendidikan.Banyak sekolah maupun perguruan tinggi berdiri di kawasan barat Malang Raya.Selain itu Kota Malang juga berusaha untuk membangkitkan pariwisatanya. Salah satu komitmennya Abah Anton, Walikota Malang, memberikan slogan "Beautifull Malang" untuk menunjang kegiatan ini (Anwar : 2015)

Banyak tersedianya fasilitas di Malang Raya ini mengakibatkan tingginya aktifitas di kota ini. Penggunaan jalan raya sebagai sarana transportasi yang menghubungkan segala tempat di Malang Raya pun tak pernah sepi dalam 24 Jam. Kualitas aspal yang bagus, serta perawatan jalan yang stabil tentu akan menunjang sustaianability. Akan tetapi, apa yang terjadi di Malang Raya adalah banyaknya lubang yang sering dikeluhkan oleh netizen dan masyarakat Malang Raya. Netizen pada media sosialnya, dan pada sebuah grup diskusi media sosial di Facebook memberikan gelar Kota Malang sebagai "WisataLubang Sewu" atau dalam bahasa Indonesianya adalah Wisata 
Lubang Seribu. Tentu ungkapan dalam ruang publik media sosial ini sebagai bentuk social distrust netizen kepada Pemerintah Kota dan Pemerintah Kabupaten yang terkesan lamban dalammasalah jalan berlubang yang ada di Malang Raya.

Menurut Komisi C DPRD Kota Malang, Bambang Sumarto menjelaskan bahwa kualitas aspal jalanan yang dikerjakan oleh dinas pekerjaan umum DPU malang raya tidak bagus. Sebenarnya ada kualitas aspal yang bagus dengan sedikit proses menambahkan pemanasan pada pemasangan aspal. (Hamzah: 2015). Selain kualitas aspal yang kurang memadai, rendahnya sistem drainase Malang Raya terhadap genangan air pada jalan juga menyebabkan aspal jalan di Malang Raya sering mengelupas, (Yayak: 2015). Rendahnya prosesmaintenance jalan di Malang Raya ini mengakibatkan aspal yang rusak itu semakin melebar pada luas jalan.

Lubang pada ruas jalan ini tidak hanya terdapat pada kawasan tertentu di Malang Raya, akan tetapi akibat penanganan yang lambat dari pemerintah kota maupun kabupaten, keberadaan lubang jalan ini semakin merata di kawasan Malang Raya. Dimulai dengan Jalan Laksamana Martadinata yang memang merupakan jalur propinsi, sampai kepada jalur alternatif seperti jalan mayjen sungkono. Walikota Malang, Abah Anton menyadari akan banyaknya jalan di Kota Malang yang memerlukan perbaikan, (Wahyuni: 2017). Menurut Abah Anton, jalan yang perlu mendapatkan perhatian terlebih dahulu adalah kawasan Jalan Panji Suroso, Jalan Ahmad Yani, Jalan Priyo Sudarmo sampai kepada jalan mergosono.

Banyaknya lubang yang diakibatkan rendahnya kualitas aspal mengakibatkan korban jatuh atau kecelakaan lalu lintas.Terutama bagi pengguna sepeda motor.Jatuh ke dalam lubang jalan bagi pengendara sepeda motor mengakibatkan kehilangan keseimbangan sampai pada akhirnya terjatuh.Tidak hanya dikarenakan dengan kecepatan yang tinggi, bahkan dengan kecepatan yang sedang, jika lubang dengan ukuran sedang sampai besar maka bisa mengakibatkan kecelakaan lalu lintas.Seperti kejadian di jalan Bandulan, ada korban akibat kecelakaan tunggal yang disebabkan oleh jalanan yang berlubang
(Indriana : 2016).Selain kecelakaan tunggal yang diakibatkan oleh lubang jalanan.Kerugian pengguna jalan lainnya adalah rusaknya salah satu onderdil kendaraan bermotor seperti velg, lampu, sampai bagian motor yang pecah.Banyaknya korban inilah yang dikeluhkan oleh sebagian besar publik Malang Raya.Timbul semacam social distrust kepada pemerintah dalam soal menangani public facility.

Penanganan yang lambat inilah yang mendorong munculya kepedulian sosial.Mereka berkumpul membentuk suatu kelompok sosial peduli jalanan berlubang di Malang Raya. Mereka memberikan kepeduliannya dengan memberikan tanda dengan menggunakan cat spray atau yang biasa disebut Pylox. Semenjak kegiatan mereka mendapatkan respon positif dari netizen, komunitas ini semakin besar.Dan skala usaha mereka pun meluas, biasanya mencakup kawasan Malang Kota, sekarang sudah sampai merambah ke Kota Batu.

Permasalahan dari penelitian ini adalah bagaimana gambaran umum dari komunitas peduli lubang jalanan Kota Malang ini.Seperti yang kita tahu, bahwa komunitas ini lahir akibat kepedulian mereka terhadap banyaknya jalanan yang berlubang di Malang Raya ini sedangkan jalanan yang berlubang itu lambat mendapat tanggapan dari Kota Malang.Kemudian permasalahn kedua dari penelitian ini adalah bagaimana persepsi masyarakat terhadap keberadaan komunitas ini?

Tujuan dari penelitian ini adalah menjawab semua permasalahan yang telah disebutkan diatas yaitu mengetahui gambaran umum komunitas peduli lubang Kota Malang.Selain itu penelitian ini berfungsi untuk menganalisis persepsi masyarakat terhadap keberadaan komunitas ini.Karena keberadaan komunitas ini tidak hanya mendapatkan reaksi positif, tetapi juga dapat reaksi negatif.

\section{METODE}

Penelitian ini menggunakan metode kualitatif dengan menggunakan pendekatan studi Kasus. Pendekatan studi kasus dilakukan apabila pertanyaan penelitian adalah apa dan mengapa. Menelaah suatu kasus secara mendalam dan intensif, mendalam, mendetail dan komprehensif. Kasus dapat diperoleh dari kasus yang unik, bersifat baru, budaya ilmiah, dan Hoolistik. Langkah penelitian dalam studi 
kasus menurut Denzin $(1994 ; 244)$ yang pertama yaitu membatasi kasus, dalam penelitian ini kasusnya adalah bagaimana persepsi masyarakat terhadap munculnya komunitas peduli lubang. Langkah kedua menurut Denzin adalah menyeleksi fenomenafenomena dalam kasus penelitian ini adalah banyaknya jalanan berlubang di Malang Raya sehingga muncul komunitas akar rumput ini. Tahapan ketiga adalah menentukan pola data untuk mengembangkan isu. Dalam penelitian ini data wawancara yang nantinya akan dikembangkan adalah bagaimana terbentuknya komunitas yang pada akhirnya menjadi sebuah gerakan protes terhadap kebijakan pemerintah dalam memperbaiki jalan yang berlubang.

\section{Tilang, Komunitas Sosial yang Lahir Melalui Kekuatan Dunia Maya}

O'brein (dalam Bungin, 2009) menjelaskan bawa perilaku manusia dan teknologi memiliki kecendrungan untuk masuk ke dalam sosioteknologi. Ada lima komponen perilaku manusia dan teknologi dalam berinteraksi yaitu (1) Struktur Masyarakat, (2) Sistem teknologi informasi, (3) Masyarakat dan Budaya, (4) Strategi Komunikasi dan (5) Proses Sosial. Kaitannya pada kasus terbentuknya Komunitas Tilang ini bermula dari sebuah grup sosialfacebookbernama "Komunitas Peduli (Asli) Malang".Grup diskusi ini sudah terbentuk sejak tahun 2010.Grup diskusi dunia maya, yang sebagai budaya populer ini terbukti sangat ampuh dalam menampung aspirasi netizen yang hampir semuanya berasal dari Malang Raya.Beberapa permasalahan yang berkaitan dengan publik policy atau konflik pribadi dapat diselesaikan melalui pertemuan yang dimulai dari diskusi di ruang publik media sosial ini.Kekecewaan pengguna jalan akibat banyaknya jalan berlubang ditumpahkan melalui media sosial Komunitas Peduli (Asli) Malang ini.Pada awalnya tiap-tiap pengguna jalan mengeluhkan kebanyakan jalan di Kota Malang yang rusak, sampai jatuh korban kecelakaan lalu lintas.Curhatan netizen yang diwadahi oleh grup sosial facebook "Komunitas Peduli (Asli) Malang"tentang jatuhnya korban yang jatuh semakin hari semakin banyak.Terhitung setiap hari rata-rata dua kasus yang dikeluhkan netizen di "Komunitas Peduli (Asli) Malang".
Seringnya keluhan kecelakaan tunggal yang diceritakan di media sosial inilah yang mendorong sebagian orang untuk melaksanakan aksinya untuk membentuk suatu komunitas agar melakukan suatu respon terhadap kasus jalan berlubang. Satu orang bernama Bayu yang memulai aksinya dengan memberikan tanda lingkaran dengan menggunakan cat spray warna putih sebagai tanda bahwa disitu terdapat lubang.Pembuatan tanda dengan lubang ini dapat terasa effect nya.Pada malam hari, tanda ini sangat terasa bedanya.

Kegiatan mereka berlangsung pada malam hari, mereka berkumpul di suatu tempat untuk merencanakan aksi sosial mereka.Pemilihan waktu malam hari adalah karena banyak anggota dari komunitas ini sudah bekerja atau kuliah, malam hari adalah waktu yang pantas untuk melaksanakan aksi mereka.Selain karena pada waktu malam yang mempertemukan mereka dari kesibukan masing, masing, adalah karena pada malam hari keamanan di jalan cukup senggang, hal ini mendorong mereka memilih waktu malam untuk menjalankan aksinya.Sejauh ini dalam melaksanakan aksinya, kelompok ini masih belum pernah mendapatkan konflik fisik dengan yang menentang aksi mereka.Konflik yang mereka alami hanyalah cibiran-cibiran pengguna media sosial yang tidak sependapat dengan aksi mereka.Meskipun tergolong pergerakan bawah tanah, akan tetapi komunitas ini mulai dilirik oleh media televisi skala nasional.

Setelah melaksanakan aksinya Bayu mengupload foto-foto kegiatannya ke dalam Grub "Komunitas Peduli (Asli) Malang". Bayu mengakuiapa yang telah dia lakukan untuk mendapatkan pengakuan sosial bahwa dirinya adalah salah satu orang yang berbuat sebagai bentuk kepedulian terhadap kota Malang.Strategi komunikasi ini dirasak an berhasil, karena banyak netizen yang memberikan respon positif. Dengan adanya respon-respon positif inilah yang mendukung netizen lain untuk ikut berpartisipasi terhadap aksi dari Bayu tersbut. Sinergi kepentingan yang sama yaitu menghendaki adanya pengakuan sosial dan kepedulian sosial terhadap kota Malang.Semakin lama keberadaan komunitas peduli lubang ini semakin dirasakan eskistensinya, jumlah anggotanya pun semakin banyak. Media komunikasi massa Grub 
"Komunitas Peduli (Asli) Malang" membuat komunitas ini semakin popular. Bayu juga mengaku sudah banyak media yang meliputnya

\section{Komunikasi Massa yang Melahirkan Social Consciusness}

Komunitas sosial Tilang lahir dari serangkaian komunikasi massa melalui media online di grup facebook "Komunitas Peduli (Asli) Malang". Secara sederhana komunikasi massa berarti pesan yang dikomunikasikan pada sejumlah orang dalam jumlah besar melalui media massa atau media sosial (Rakhmat : 188). Katika individu memberikan informasi atau sekedar berkeluh kesah, maka orang lain melihat respon, maka terjadilah proses komunikasi. Komunikasi tersebut tentunya akan menimbulkan efek, menurut Karlinah dan kawan-kawan (2009:52) komunikasi di media massa atau media sosial dapat menimbulkan efek-efek Kognitif, efek afektif, dan efek behavorial. Efek kognitif adalah efek akibat yang timbul pada diri komunikan yang sifatnya informative bagi dirinya. Dalam efek kognitif akan dibahas tentang bagaimana media massa dan media sosial dapat membantu khalayak mempelajari informasi yang bermanfaat dalam mengembangkan kemampuan kognitifnya. Efek kognitif terjadi apabila ada yang diketahui dan difahami, atau diapresiasi oleh khalayak.Untuk Efek afektif, kondisinya lebih tinggi bila dibandingkan dengan efek kognitif. $\mathrm{T} \mathrm{u} \mathrm{j} \mathrm{u} \mathrm{a} \mathrm{n}$ dari komunikasi massa bukan sekedar memberitahu khalayak akan sebuah informasi, akan tetapi penerima respons akan dapat bisa merasa terharu, iba gembira, marah dan sebagainya. Sedangkan efek behavorial merupakan akibat dari dampak yang berupa perilaku ketika menerima respons dari komunikan.

Pada kasus dalam penelitian ini, bahwa terbentuknya komunitas Tilang itu sudah sampai pada tahapan efek afektif, pembentukan komunitas berdasarkan kesadaran dan kesamaan respons masyarakat yang tegabung dalam komunikasi massa di grup facebook "Komunitas Peduli (Asli) Malang". Gerakan menandai jalan memang dimulai oleh Bayu, namun akibat dia mempublikasikan, dia menginginkan sebuah pengakuan publik kepada dirinya inilah yang mengakibatkan komunitas Tilang ini berkembang.Selain itu kegiatan sosial ini membutuhkan sebuah legitimasi masyarakat untuk dapat sustainable.

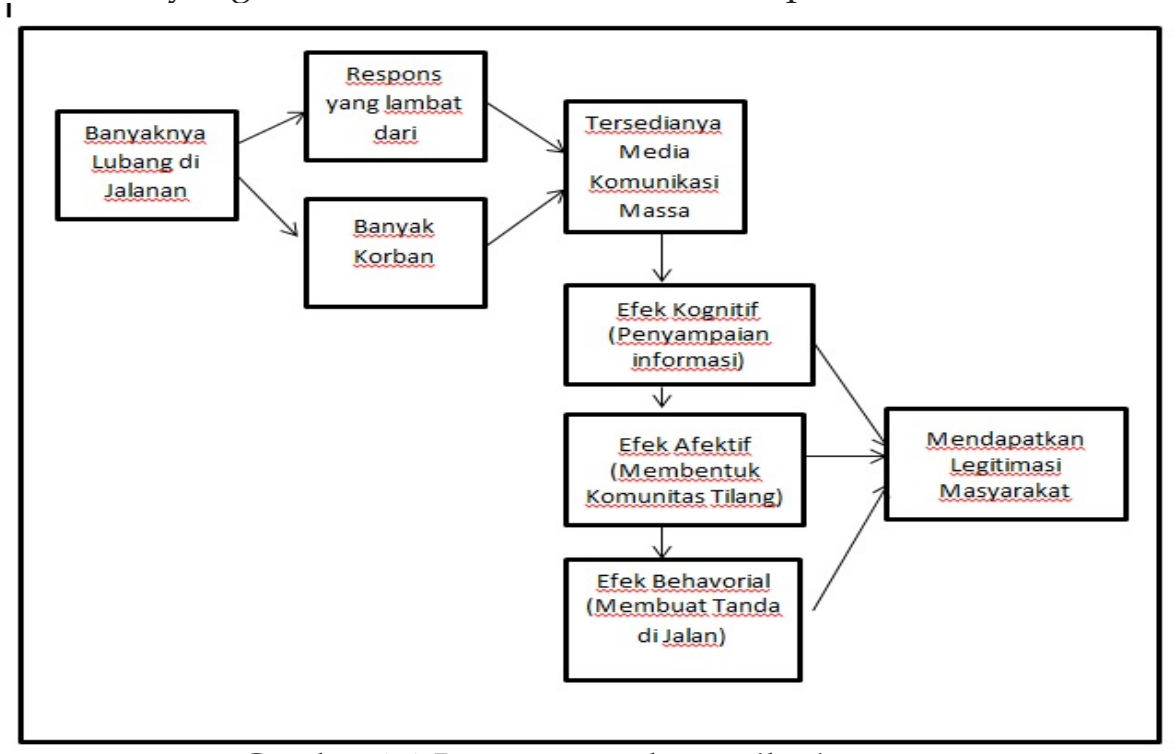

Gambar 1.1 Bagan proses komunikasi massa

Dalam hal ini kesadaran sosial atau Social Consciusnesslahir pada tahapan afektif.Hanya saja bedanya dengan legitimasi masyarakat, proses legitimasi masyarakat bisa berlangsung pada ketiga tahap yaitu tahap kognitif, tahap afektif, dan tahap behavorial. Karena masyarakat pada kasus banyaknya lubang di kota malang cenderung memberikan apresiasi sejak proses netizen atau masyarakat melaporkan banyaknya lubang pada media komunikasi massa yang disini adalah grup facebook "Komunitas Peduli (Asli) Malang".Berkumpulnya sekelompok orang yang peduli terhadap fasilitas umum yang rusak disini lah yang mendorong terbentuknya komunitas Tilang yang dipelopori oleh Bayu.Perbincangan dan persoalan tentang 
kesadaran sosial ini adalah merupakan masalah klasik.Kesadaran yang bermula dari kesadaran individu inilah yang berkembang menjadi kesadaran sosial.Pada dasarnya grup facebook "Komunitas Peduli (Asli) Malang" adalah sebagai ruang publik yang dilegitimasi masyarakat pengguna sosial media sebagai salah satu media komunikasi massa untuk halhal kepentingan masyarakat Kota Malang.Kesadaran sosial ini timbul dengan sendirinya, apalagi setelah ada korban berjatuhan. Kesadaran sosial masyarakat timbul dengan bantuan media komunikasi massa. Media tersebut menggugah Social Consciusnessagar tiap netizen ikut berpartisipasi kegiatan pembentukan komunitas Tilang ini.

\section{Analisis Persepsi Masyarakat}

Publik Malang Raya mengenal komunitas peduli lubang melalui grup facebook “Komunitas Peduli (Asli) Malang. Mengenal komunitas ini tentu akan menghasilkan persepsi beragam. Rahmat (2005) mengemukakan bahwa dua jenis persepsi tersebut adalah persepsi positif dan negatif. Apabila suatu hal yang dipersepsi sesuai dengan penghayatan dan dapat diterima secara rasional dan emosional maka seorang akan mempersepsikan secara positif, namun apabila tidak memenuhi dengan kriteria tersebut maka akan cenderung menjauhi, menolak, dan menanggapi secara berlawan objek persepsi tersebut. Persepsi positif merupakan penilaian individu terhadap suatu objek, sesuai Dalam analisis frekuensi yang didapat adalah :

\begin{tabular}{|c|c|c|c|}
\hline No & Persepsi & $\%$ & Alasan \\
\hline 1 & Positif & 80 & $\begin{array}{l}\text { 1. Jalan adalah fasilitas publik, kepedulian } \\
\text { terhadap fasilitas umum tentu memberikan } \\
\text { pesan positif } \\
\text { 2. Banyaknya korban jatuh mengakibatkan } \\
\text { dukungan terhadap keberadaan komunitas ini } \\
\text { 3. Kecintaan terhadap kota Malang, mendorong } \\
\text { seseorang untuk tetap mendukung eksi stensi } \\
\text { komunitas Tilang } \\
\text { 4. Penanganan yang lambat dari pemerintah } \\
\text { menandakan terbentuknya komunitas ini } \\
\text { sebagai bentuk perlawanan }\end{array}$ \\
\hline 2 & Negatif & 20 & $\begin{array}{l}\text { 1. Aksi yang tidak memberikan solusi } 100 \% \text { ini } \\
\text { memberikan anggapan bahwa hal ini adalah } \\
\text { perbuatan yang sia-sia } \\
\text { 2. Sekilas memang aksi ini mirip vandalism } \\
\text { yang pernah meresahkan warga malang } \\
\text { trauma juga mempengaruhi persepsi negatif } \\
\text { masyarakat } \\
\text { 3. Penggunaan kalimat -kalimat kasar dan tidak } \\
\text { pantas mengurangi kepercayaan masyarakat } \\
\text { terhadap eksistensi komunitas ini }\end{array}$ \\
\hline
\end{tabular}

Tabel 1.1 Persentase persepsi responden

Dari keseluruhan responden, memang tingkat kepuasan masyarakat Malang Raya dan netizen pengguna media komunikasi massa memang cenderung simpatik dan mendukung eksistensi komunitas sosial ini. Masyarakat berpikir, kalau tidak ada komunitas ini lalu siapa yang bersedia melakukan aksi sosial ini.Masyarakat menaikkan rating komunitas ini dengan aktif memberikan respons positif di media sosial maupun dalam pelaksanaan di dunia nyata.Masyarakat juga menyadari bahwa dukungan mereka akan membuat komunitas ini akan tetap hidup. Apresiasi dukungan juga sebagai bentuk kekecewaan masyarakat malang raya yang rajin membayar pajak, akan tetapi pemerintah kota dan kabupaten yang bergerak lamban menangani keluhan-keluhan masyarakat. 
Selain dukungan yang bersifat menaikkan rating, masyarakat malang raya juga memberikan bantuan cat semprot (Pylox). Mereka sadar tidak mempunyai cukup waktu untuk bergabung dengan komunitas ini, namun masyarakat ikut mendukung aksi mereka dengan memberikan segala macam logistic keperuan untuk komunitas ini melaksanakan aksinya.

\section{KESIMPULAN}

Komunitas Tilang atau komunitas peduli lubang jalanan kota malang memulai aksinya melalui seorang individu, dimulai dari kesadararan individu, kemudian individu mengunggahnya ke media sosial dalam rangka untuk mendapatkan pengakuan publik. Budi selain peduli, dia ingin mendapatkan popularitas dan pengakuan dari publik melalui aksinya.Budi semakin bersemangat ketika aksinya mendapatkan dukungan moril dari masyarakat, terutama dari kalangan netizen.Komunitas terbentuk dikarenakan kesamaan persepsi bahwa jalanan yang berlubang perlu mendapatkan perhatian dari pemerintah.Pemerintah disini berperan sebagai bentukan dominasi, kaum dominan enggan merespon suara dari masyarakat.Masyarakat melakukan aksi perlawanan dengan bentuk sindiran yaitu dengan menandai jalan yang berlubang dengan pylox putih.Meski aksi mereka tidak sepenuhnya membuahkan solusi, setidaknya melalui aksi ini memberikan peringatan bahwa pergerakan itu melalui akar rumput.Komunitas Tilang hadir sebagai perlawanan akar rumput yang dimulai dari masyarakat bawah. Komunitas ini akan selalu mendapatkan legitimasi masyarakat, meskipun aksi mereka bukan merupakan solusi sampai selesai, namun aksi mereka merupakan aksi progressive yang membuat pemerintah kota bergerak. Respon pemerintah positif terhadap keberadaan komunitas ini.

Pemerintah kota dan kabupaten malang hendaknya merespon cepat dan segera melaksanakan perbaikan menyeluruh terhadap permasalahan yang berhubungan dengan fasilitas publik ini. Pergerakan sosial yang dimulai dari kesadaran sosial inilah yang seharusnya menggerakkan pemerintah agar melakukan maintenance dengan cepat. Respon yang lambat dari pemerintah dan penundaan maintenance hanya akan berakibat bertambahnya korban akibat jalanan yang rusak. Komunitas Tilang juga perlu menjaga nama baik dan eksistensi mereka dengan menggunakan kalimat-kalimat positif dalam coretan mereka. Sehingga perspektif masyarakat yang negatif dapat berkurang

\section{DAFTAR RUJUKAN}

\section{Buku}

Ardianto, E., Lukiati, K. dan Siti, K. 2009, Komunikasi Massa, Bandung, Simbiosa Rekatama Media.

Bungin, B. P. Sosiologi Media, Komunikasi Sosial, Teknologi Informatika, Kebudayaan Seks di Media Massa. Prenada Media Group, Bandung.

Denzin, N. K. dan Lincoln, Y. S. (Eds), 1994. The Handbook of Qualitative Research Thousand Oaks, CA: Sage

Rakhmad, J. 1994. Psikologi Komunikasi, Bandung, Remaja Rosdakarya

\section{Internet :}

Anwar, K. http://www.malangtimes.com/ baca/3365/20150823/174547/hari-iniabah-anton-resmi-melaunching-beautifulmalang-/ diakses 12 Februari 2017, 06.30

Hamzah, M. N. http://malangvoice.com/ aspal-mudah-rusak-bambang-kualitasnyajelek/, Diakses 12 Februari 2017, 21.00

Indriana, M. https:/ / malangtoday.net/malangraya/banyak-warga-terjatuh-akibat-jalanrusak-di-bandulan/ Diakses 12 Februari 2017, 20.00

Yayak. 2015 http://radarmalang.co.id/barusebulan-aspal-mengelupas-25271.htm, Diakses 12 Februari 2017 Pukul 07.00

Wahyuni. http:// suryamalang.tribunnews.com/2017/02/ 07/2018-target-perbaikan-jalan-berlubangdi-kampung-di-kota-malang-harus-selesai, Diakses 6 Februari 2017 
Faisal, Analisis Persepsi Masyarakat .... ॥19 


\title{
ANALISIS KEBUTUHAN BELAJAR UNTUK MENYUSUN PERANGKAT PEMBELAJARAN BIPA TINGKAT PEMULA YANG BERORIENTASI AMERICAN COUNCIL FOR TEACHING FOREIGN LANGUAGE (ACTFL)
}

\author{
Azza Aulia Ramadhani \\ Program Studi Pendidikan Bahasa dan Sastra Indonesia \\ IKIP Budi Utomo Malang, \\ Jalan Citandui 46 Malang \\ Email. azzauliaramadhani@gmail.com
}

\begin{abstract}
This study aims to obtain an objective description of the results of learniing needs analysis for BIPA's learners at beginner level to arrange learning tools. This research uses qualitative design with descriptive approach. The data of this research are words and documents which are then analyzed. Based on the results of the analysis obtained conclusions, namely the results of learning needs analysis BIPA's students at beginner level.
\end{abstract}

Keywods: need analysis, learning tool, BIPA, ACTFL

Keberadaan bahasa Indonesia untuk penutur asing (BIPA) bukan merupakan fakta baru. Sejak zaman penjajahan Belanda, bahkan bahasa Indonesia telah dipelajari oleh orang asing. Bahkan, jauh sebelum itu, bangsa Indonesia mulai dikenal dan wilayah Indonesia mulai menjadi sasaran kunjungan orang-orang asing, bahasa Indonesia sudah dikenal dan dipelajari oleh mereka (Suyitno, 2004). Seiring dengan perkembangan jaman, pengajaran BIPA di Indonesia memiliki peranan yang sangat penting terkait dengan posisi Indonesia dalam percaturan dunia yang semakin hari semakin penting pula. Apalagi dengan akan dibukanya pasar bebas di ASEAN, pada masa yang akan datang hal ini akan memperbesar peluang bagi orang asing untuk memasuki berbagai wilayah di Indonesia. Hal ini yang menyebabkan orang asing harus belajar bahasa Indonesia agar dapat berkomunikasi lebih baik dengan pejabat, teman sejawat, ataupun masyarakat umum di Indonesia. Dengan demikian, kondisi tersebut menuntut lebih banyak lagi kebutuhan program pengajaran BIPA.

Berkaitan dengan pentingnya program pengajaran BIPA di Indonesia, yang perlu pendapat perhatian adalah pelaksanaan pengajarannya. Hingga saat ini belum tersedia kurikulum pembelajaran BIPA yang disusun oleh lembaga pembelajaran bahasa Indonesia untuk penutur asing. Oleh karena itu, dibutuhkan kurikulum atau perangkat pembelajaran yang memenuhi standar dan kebutuhan belajar orang asing, sehingga tidak perlu mengadaptasi standar pembelajaran bahasa asing yang disusun oleh lembaga pembelajaran bahasa asing Eropa, Amerika, ataupun Australia. Selain itu, diperlukan perangkat pembelajaran yang mampu menggiring pembelajaran bahasa Indonesia untuk penutur asing berjalan lebih efektif. Mengingat setiap orang asing yang datang untuk belajar bahasa Indonesia memiliki tujuan yang berbeda sehingga kebutuhan belajar pun menjadi berbeda.

Bila dilihat dari kondisi pelajarnya, pengajaran BIPA di Indonesia memliki karakteristik yang berbeda dengan pengajaran bahasa Indonesia pada umumnya. Pelajar BIPA adalah pelajar asing yang memiliki latar belakang budaya yang berbeda dengan budaya bahasa yang dipelejarinya. Selain itu, kebanyakan pelajar BIPA di Indonesia adalah pelajar dewasa. Sesuai dengan kenyataan tersebut, Wojowasito (dalam Suyitno, 2004) menjelaskan bahwa perbedaan terpenting antara pengajaran BIPA dengan pengajaran bahasa Indonesia pada umumnya adalah (1) BIPA tidak mengintegrasikan anak ke dalam lingkungannya, (2) BIPA hampir dipelajari pada usia dewasa atau pada ketika seseorang telah menguasai sejumlah struktur dari bahasa pertamanya, dan (3) BIPA diolah diluar sistemnya sendiri, dari sistem yang biasanya berbeda.

Richards (2001) mengemukakan bahwa salah satu asumsi dasar dari pengembangan kurikulum adalah program pendidikan yang 
dilaksanakan harus didasarkan pada analisis kebutuhan belajar pelajar. Prosedur ini bermanfaat untuk mengumpulkan informasi tentang kebutuhan pelajar. Hal ini berkaitan dengan pembelajaran bahasa tidak lepas dari keterampilan berbahasa yang dimiliki seseorang. Seperti pembelajaran bahasa pada umumnya, program BIPA mempunyai empat keterampilan berbahasa dalam pelajarannya yang terdiri atas empat komponen, yaitu (a) keterampilan menyimak atau listening skill, (b) keterampilan berbicara atau speaking skill, (c) keterampulan membaca atau read-ing skill, dan (d) keterampilan menulis atau writing skill. Keterampilan menyimak atau listening skill dan keterampilan membaca atau reading skill termasuk dalam keterampilan reseptif, sedangkan keterampilan berbicara atau speaking skill dan keterampilan menulis atau writing skill termasuk dalam keterampilan produktif. Baik belajar bahasa untuk tujuan khusus (BIPA) maupun belajar bahasa Indonesia untuk tujuan umum, bagi pelajar bahasa Indonesia digunakan sebagai alat. Bahasa Indonesia difungsikan sebagai alat komunikasi baik secara lisan maupun tulis. Oleh karena itu, dalam pembelajaran BIPA, tujuan yang ingin dicapai adalah kemampuan pelajar untuk berkomunikasi dengan menggunakan bahasa Indonesia yang dipelajarinya. Dengan demikian, pelajar diharapkan dapat memiliki kemampuan komunikatif. Berdasarkan alasan tersebutlah, perangkat pembelajaran yang akan dikembangkan hanya fokus pada pembelajaran menulis dan berbicara.

Perangkat pembelajaran yang dikembangkan berpedoman pada korespondensi skala kemahiran American Council for Teaching Foreign Language (ACTFL). Peneliti memilih pedoman American Council for Teaching Foreign Language (ACTFL) karena ada beberapa keunggulan yang dimiliki oleh ACTFL dan tidak dimiliki oleh korespondensi skala kemahiran lain. Salah satu keunggulan ACFTL yang paling menonjol adalah pengklasifikasian kemampuan berbahasa pelajar berdasarkan empat keterampilan berbahasa. Keunggulan ini tidak dimiliki oleh skala korespondensi skala kemahiran berbahasa yang lain, misalnya, The Common European of Reference for Languages (CEFR). Selain itu, pelevelan yang terdapat dalam American Council for Teaching Foreign Language (ACTFL) lebih rinci karena ada 11 level, yaitu native, distinguished, superior, advance plus, advance, intermediate high, intermediate mid, intermediate low, novice high, novice mid, dan novice low. Maka, tujuan dari penelitian ini adalah untuk mendeskripsikan hasil analisis kebutuhan belajar dan disesuaikan dengan pedoman kemahiran berbahasa American Council for Teaching Foreign Language (ACTFL) untuk menyusun perangkat pembelajaran BIPA tingkat pemula.

\section{METODE}

Penelitian Perangkat Pembelajaran BIPA Tingkat Pemula yang Berorientasi American Council for Teaching Foreign Language (ACTFL) ini merupakan jenis penelitian kualitatif. Pendekatan kualitatif dalam penelitian ini didasarkan dua pertimbangan. Pertama, penelitian ini bersifat induktif, yaitu pengembangan kon-sep didasarkan data yang ada. Kedua, penelitian ini bersifat deskriptif, artinya penelitian berusaha membuat deskripsi secara sistematis, faktual dan akurat mengenai fakta-fakta, sifat-sifat, serta hubungan antar fenomena yang diselidiki. Hal tersebut sejalan dengan pendapat Hasan (1990:16) yang menyatakan bahwa penelitian kualitatif selalu bersifat deskriptif, artinya data yang dianalisis dan hasil analisisnya berbentuk deskripsi fenomena, tidak berupa angka-angka atau koefisien tentang hubungan antarvariabel. Oleh karena itu, instrumen penelitian dalam penelitian ini adalah peneliti sendiri yakni, peneliti sendiri yang berperan sebagai observer dan sekaligus penganalisis data.

Data dalam penelitian ini berupa skala kemahiran belajar bahasa American Council for Teaching Foreign Language (ACTFL) dan hasil observasi yang diperoleh melalui wawancara. Data yang hasil wawancara ini dideskripsikan untuk menghasilkan sebuah kesimpulan. Berdasarkan data tersebut, sumber data dalam penelitian ini adalah pedoman pelevelan ACTFL dan hasil wawancara dengan pengajar BIPA. Instrumen yang digunakan dalam penelitian ini adalah peneliti sendiri sebagai instrumen kunci. Selain itu, peneliti juga menggunakan instrumen pembantu yang berupa pedoman wawancara.

\section{HASIL}

Berdasarkan wawancara yang dilakukan pada pengajar BIPA, ditemukan beberapa 
permasalahan. Permasalahan ini berkaitan dengan keterampilan yang akan diajarkan dan dilatihkan serta beberapa materi yang dirasa sulit disampaikan oleh guru. Wawancara ini dilakukan dengan menggunakan pedoman wawancara kepada guru.

Pembelajaran bahasa tidak lepas dari keterampilan berbahasa yang dimiliki seseorang. Tidak berbeda pembelajaran bahasa pada umumnya, program BIPA mempunyai empat keterampilan berbahasa dalam pelajarannya yang terdiri atas empat komponen, yaitu (a) keterampilan menyimak atau listening skill, (b) keterampilan berbicara atau speaking skill, (c) keterampulan membaca atau read-ing skill, dan (d) keterampilan menulis atau writing skill. Keterampilan menyimak atau listening skill dan keterampilan membaca atau reading skill termasuk dalam keterampilan reseptif, sedangkan keterampilan berbicara atau speaking skill dan keterampilan menulis atau writing skill termasuk dalam keterampilan produktif. Baik belajar bahasa untuk tujuan khusus (BIPA) maupun belajar bahasa Indonesia untuk tujuan umum, bagi pelajar bahasa Indonesia digunakan sebagai alat. Bahasa Indonesia difungsikan sebagai alat komunikasi baik secara lisan maupun tulis. Oleh karena itu, dalam pembelajaran BIPA, tujuan yang ingin dicapai adalah kemampuan pelajar untuk berkomunikasi dengan menggunakan bahasa Indonesia yang dipelajarinya. Dengan demikian, pelajar diharapkan dapat memiliki kemampuan komunikatif. Berdasarkan alasan tersebutlah, perangkat pembelajaran yang akan dikembangkan hanya fokus pada pembelajaran menulis dan berbicara.

Baik belajar bahasa untuk tujuan khusus (BIPA) maupun belajar bahasa Indonesia untuk tujuan umum, bagi pelajar bahasa Indonesia digunakan sebagai alat. Bahasa Indonesia difungsikan sebagai alat komunikasi baik secara lisan maupun tulis. Oleh karena itu, dalam pembelajan BIPA, tujuan yang ingin dicapai adalah kemampuan pelajar untuk berkomunikasi dengan menggunakan bahasa Indonesia yang dipelajarinya. Dengan demikian, pelajar diharapkan dapat memiliki kemampuan komunikatif (Suyitno, 2004). Berdasarkan tujuan komunikatif itulah, guru menggunakan metode celup total dalam mengajarkan bahasa Indonesia pada penutur asing. Metode celup total yang dimaksud adalah guru menggunakan bahasa Indonesia saja sebagai bahasa pengantar di kelas. Guru berupaya tidak menggunakan bahasa Inggris dalam menyampaikan materi. Hal tersebut dilakukan agar pelajar asing terbiasa dan semakin cepat lancar dalam berbahasa Indonesia. Namun, kendala yang dialami guru adalah ketika siswa tidak memahami materi yang disampaikan dan guru pun terkadang kesulitan dalam menjawab pertanyaan pelajar asing dengan kalimat bahasa Indonesia yang sederhana apabila pelajar yang dihadapi adalah pelajar pemula.

\section{PEMBAHASAN}

\section{Pembelajaran BIPA Tingkat Pemula}

Guru menggunakan metode celup total dalam mengajar. Hal ini dilakukan agar tujuan komunikatif dapat tercapai sesuai dengan waktu yang telah ditentukan. Hal tersebut sesuai dengan pendapat Suyitno (2004) yang menjelaskan bahwa dalam kaitannya dengan teknik pembelajaran BIPA, ada beberapa hal yang dikaji, yaitu (1) teknik penyampaian materi, (2) teknik menghadapi pelajar, dan (3) teknik penciptaan suasana belajar. Teknik penyampaian materi dibagi dalam 3 tahap, yakni teknik membuka pelajaran, teknik menyampaikan materi baru, dan teknik menutup pelajaran. Teknik yang digunakan oleh guru dalam menyampaikan materi pada dasarnya menggunakan teknik celup total. Guru berusaha sedapat mungkin tidak menggunakan bahasa Inggris. Berbagai cara yang digunakan untuk penyajian materi tersebut diantaranya adalah cara tanya jawab, pelatihan, penugasan, demostrasi, pemberian konsultasi baik kelompok maupun individual, tutorial, penubian (drill), dan koreksi.

Dalam pembelajaran BIPA di Indonesia, ancangan komunikatif sangat mungkin untuk dapat diterapkan, karena BIPA diajarkan ditempat bahasa tersebut digunakan. Ada beberapa keuntungan yang diperoleh apabila BIPA diajarkan di lingkungan penutut asli, yakni (1) bahan-bahan otentik tidak terlalu sulit diperoleh, misalnya dari brosur, TV, surat kabar, dan lain-lain; (2) kegiatan di kelas dapat dihubungkan dengan tugas di luar kelas atau tugas terstruktur yang lain; (3) pemahaman dan 
pengalaman dalam hubungan bahasa dan budaya menjadi lebih konkret; dan (4) masalah gegar budaya yang dialami pelajar dapat diatasi dengan membina hubungan yang baik antara pelajar, pengajar dan masyarakat (Sutiyono dalam Suyitno, 2004).

Pengembangan materi membaca dan menulis disesuaikan dengan tingkat kemampuan pelajarnya. Untuk tingkat pemula diberikan bacaan dalam bahasa Indonesia yang agak kompleks, dan untuk tingkat lanjut diberikan bacaan bahasa Indonesia yang kompleks. Materimateri bacaan sederhama banyak diambilkan dari bacaan yang ada di majalah anak-anak, bacaan yang ada pada buku dasar, atau bacaan yang disusun sendiri oleh pengajar. Adapun untuk materi menulis dimulai dari menulis kalimat, menulis topik sederhana tentang pengalaman pribadi pelajar, atau apa yang telah dilakukannya sampai dengan menulis makalah untuk diseminarkan dalam seminar di kelasnya.

Sejalan dengan uraian tentang kompetensi komunikatif di atas, lebih lanjut Hymes (1971) menjelaskan bahwa agar seseorang dapat berkomunikasi secara efektif dalam suatu bahasa, ia memerlukan pengetahuan berikut, yakni (1) pengetahuan tentang bentuk bahasa yang mungkin dikatakan, (2) pengetahuan tentang kata yang dapat dituturkan dan dapat dipahami oleh pendengar, (3) pengetahuan tentang kata yang sesuai dan lazim menurut konteksnya, dan (4) pengetahuan tentang kata yang pernah diujarkan orang. Dengan penguasaan keempat hal tersebut seseorang dapat berbahasa secara berterima.

\section{Analisis Kebutuhan Belajar Pelajar BIPA Tingkat Pemula}

Richards (2001) mengemukakan bahwa salah satu asumsi dasar dari pengembangan kurikulum adalah program pendidikan yang dilaksanakan harus didasarkan pada analisis kebutuhan belajar pelajar. Prosedur ini bermanfaat untuk mengumpulkan informasi tentang kebutuhan pelajar. Oleh karena itu, sebelum memulai mengembangkan perangkat pembelajaran BIPA, perlu dilakukan analisis kebutuhan belajar pelajar asing. Analisis kebutuhan belajar yang dilakukan bertujuan untuk mengetahui alasan dan tujuan mereka dalam mempelajari bahasa Indonesia. Hal ini mempengaruhi pemilihan materi yang disajikan dalam silabus. Selain itu, latar belakang budaya pelajar juga turut mempengaruhi materi yang akan disajikan, mengingat setiap pelajar dari negara yang berbeda akan memiliki kebiasaan belajar yang berbeda pula sehingga hal tersebut berpengaruh terhadap pemilihan metode pembelajaran yang dilaksanakan di dalam kelas. Hal tersebut sesuai dengan hasil penelitian yang telah dilakukan oleh Deneme (2010) yang mengungkapkan bahwa latar belakang budaya turut mempengaruhi pilihan strategi pembelajaran yang digunakan di dalam kelas. Selain itu, orang-orang dari budaya yang berbeda akan belajar dengan cara yang berbeda pula. Mahasiswa Yordania, misalnya, sering menggunakan metode hafalan dalam belajar. Tidak terkecuali dalam belajar bahasa. Mahasiswa Yordania berulang kali mengucapkan atau menulis kata-kata bahasa Inggris yang baru diberikan oleh guru. Hal tersebut berbeda dengan cara belajar mahasiswa Turki dan juga mahasiswa Spanyol. Mahasiswa Spanyol lebih sering dilatih menulis untuk mengasah kemampuan berbahasa Inggris mereka. Mahasiswa tidak hanya dilatih untuk menulis secara formal, tetapi juga dilatih menulis catatan harian. Hal tersebut dilakukan agar mahasiswa tidak hanya memahami teori, tetapi juga mempraktikkannya dalam kehidupan sehari-hari agar pembelajarab yang telah dilakukan lebih bermanfaat. Metode menulis catatan harian juga digunakan dalam pembelajaran bahasa Indonesia untuk penutur asing (BIPA). Catatan harian yang ditulis mahasiswa berbentuk jurnal yang digunakan untuk memantau perkembangan kemampuan berbahasa Indonesia si pelajar asing.

Pembelajaran bahasa tidak lepas dari keterampilan berbahasa yang dimiliki seseorang. Seperti pembelajaran bahasa pada umumnya, program BIPA mempunyai empat keterampilan berbahasa dalam pelajarannya yang terdiri atas empat komponen, yaitu (a) keterampilan menyimak atau listening skill, (b) keterampilan berbicara atau speaking skill, (c) keterampulan membaca atau read-ing skill, dan (d) keterampilan menulis atau writing skill. Keterampilan menyimak atau listening skill dan keterampilan membaca atau reading skill termasuk dalam keterampilan reseptif, sedangkan keterampilan 
berbicara atau speaking skill dan keterampilan menulis atau writing skill termasuk dalam keterampilan produktif. Baik belajar bahasa untuk tujuan khusus (BIPA) maupun belajar bahasa Indonesia untuk tujuan umum, bagi pelajar bahasa Indonesia digunakan sebagai alat. Bahasa Indonesia difungsikan sebagai alat komunikasi baik secara lisan maupun tulis. Oleh karena itu, dalam pembelajaran BIPA, tujuan yang ingin dicapai adalah kemampuan pelajar untuk berkomunikasi dengan menggunakan bahasa Indonesia yang dipelajarinya. Dengan demikian, pelajar diharapkan dapat memiliki kemampuan komunikatif. Berdasarkan alasan tersebutlah, perangkat pembelajaran yang akan dikembangkan hanya fokus pada pembelajaran menulis dan berbicara.

Perangkat pembelajaran yang dikembangkan berpedoman pada korespondensi skala kemahiran American Council for Teaching Foreign Language (ACTFL). Bagan berikut memberikan hubungan antara tingkatan dari ACTFL dan skala kemahiran ILR.

Tabel 1 Bagan Perbandingan

\begin{tabular}{|c|c|c|}
\hline $\begin{array}{l}\text { Skala } \\
\text { ILR }\end{array}$ & Skala ACTFL & Definisi \\
\hline 5 & Native & $\begin{array}{l}\text { Mampu berbicara seperti penutur asli } \\
\text { yang berpendidikan }\end{array}$ \\
\hline $4+$ & Distinguished & $\begin{array}{l}\text { Mampu berbicara dengan kelancaran, } \\
\text { ketepatan tatabahasa, ketelitian kosakata } \\
\text { dan idiomatik yang baik. }\end{array}$ \\
\hline $3+$ & Superior & $\begin{array}{l}\text { Mampu menggunakan suatu bahasa } \\
\text { dengan akurasi struktu r dan kosakata } \\
\text { yang memadai untuk berpartisipasi secara } \\
\text { efektif dalam percakapan pada } \\
\text { lingkungan formal dan informal. }\end{array}$ \\
\hline $2+$ & Advance Plus & $\begin{array}{l}\text { Mampu memenuhi sebagian besar } \\
\text { persyaratan pekerjaan dan menunjukkan } \\
\text { beberapa kemampuan untuk } \\
\text { berkomunikasi pada topik -topik yang } \\
\text { konkrit. }\end{array}$ \\
\hline 2 & Advance & $\begin{array}{l}\text { Mampu memenuhi tuntutan sosial rutin } \\
\text { dan persyaratan kerja yang terbatas. }\end{array}$ \\
\hline $1+$ & Intermediate - High & $\begin{array}{l}\text { Mampu memenuhi sebagian besar } \\
\text { kebutuhan dasar untuk bertahan hidup } \\
\text { dan tuntutan sosial yang terbatas. }\end{array}$ \\
\hline 1 & $\begin{array}{l}\text { Intermediate - Mid } \\
\text { Intermediate - Low }\end{array}$ & $\begin{array}{l}\text { Mampu memenuhi beberapa kebutuhan } \\
\text { dasar untuk hidup dan beberapa tuntutan } \\
\text { sosial yang terbatas. } \\
\text { Mampu memenuhi kebutuhan dasar } \\
\text { untuk bertahan hidup dan persyaratan } \\
\text { minimum kesopanan }\end{array}$ \\
\hline $0+$ & Novice - High & $\begin{array}{l}\text { Mampu memenuhi kebutuhan yang } \\
\text { mendesak dengan tuturan yang dipelajari. }\end{array}$ \\
\hline 0 & $\begin{array}{l}\text { Novice - Mid } \\
\text { Novice - Low } \\
0\end{array}$ & $\begin{array}{l}\text { Hanya mampu menggunakan bahasa } \\
\text { dalam kapasitas yang terbatas. } \\
\text { Tidak dapat berbicara dalam bahasa lisan. } \\
\text { Tidak memiliki kemampuan apapun } \\
\text { dalam bahasa. }\end{array}$ \\
\hline
\end{tabular}


Berikut adalah rincian kemampuan yang dimiliki oleh pembelajar tingkat pemula berdasarkan pedoman ACTFL.

1) Pedoman ACTFL: Mendengarkan Novice

a) Novice-Low

Pemahaman terbatas pada kata-kata yang terisolasi, seperti cognate (bahasa yang sama asalnya), borrowing words (kata-kata pinjaman), dan kaidah-kaidah sosial kemasyarakatan yang umum digunakan. Pada dasarnya tidak mempunyai kemampuan untuk memahami bukan untuk ucapan-ucapan pendek sekalipun.

b) Novice-Mid

Mampu memahami beberapa ujaranujaran pendek yang dipelajari, terutama saat konteks mendukung pemahaman dengan kuat dan berbicaranya terdengar dengan jelas. Memahami beberapa kata dan frasa dari pertanyaan sederhana, pernyataan, perintah yang sering digunakan dan formula kesopanan tentang topik yang merujuk pada informasi pribadi atau situasi fisik langsung. Pendengar memerlukan jeda waktu yang panjang untuk memahami ujaran dan secara berkala meminta pengulangan dan/atau meminta memperlambat kecepatan berbicara.

c) Novice-High

Mampu memahami ujaran-ujaran pendek yang dipelajari dan beberapa ujaran kalimat-kalimat panjang, khususnya saat konteks mendukung pemahaman dengan sangat kuat dan berbicaranya terdengar dengan jelas. Memahami kata dan frasa dari pertanyaan sederhana, pernyataan, perintah-perintah yang sering digunakan, dan formula kesopanan. Mungkin memerlukan pengulangan, mengulang, dan/atau melambatkan kecepatan berbicara untuk tujuan pemahaman.

2) Pedoman ACTFL: Berbicara - Novice

Deskripsi Umum

Tingkatan Novice dicirikan oleh kemampuan untuk berkomunikasi yang paling tidak dengan metri yang telah dipelajari.

a) Novice-Low
Produksi lisan terdiri atas kata-kata yang terisolasi dan mungkin beberapa frase yang umum digunakan. Pada dasarnya tidak memiliki kemampuan komunikatif fungsional.

b) Novice-Mid

Meskipun kuantitasnya ditingkatkan, produksi lisan terdiri atas kata-kata yang terisolasi dan frase yang dipelajari dalam wilayah kebutuhan yang telah diprediksi sebelumnya. Kosakata hanya cukup untuk menangani kebutuhan dasar, sederhana untuk mengekspresikan nilainilai kesopanan dasar. Jarang sekali terjadi ujaran yang terdiri atas atau lebih dari dua atau tiga kata dan sering menunjukkan jeda yang panjang dan pengulangan kata-kata dari lawan bicara. Pembicara mungkin memiliki beberapa kesulitan menghasilkan bahkan pada ucapan-ucapan sederhana sekalipun. Membutuhkan usaha yang besar dalam memahami ujaran atau ucapan dari siswa pada tingkat ini.

c) Novice-High

Mampu memenuhi sebagian persyaratan dari pertukaran komunikatif dasar dengan bergantung pada tuturan yang telah dipelajari tetapi kadang-kadang memperluas komunikasi tersebut melalui rekombinasi sederhana unsur-unsurnya. Bisa bertanya atau membuat pernyataan sesuai dengan materi yang telah dipelajari. Menunjukkan tanda-tanda spontanitas walaupun hanya sedikit ekspresi mereka yang sesuai dengan konteks yang sesungguhnya. Pembicaraan hanya terdiri atas ujaranujaran yang telah dipelajari yang disesuaikan dengan situasi tertentu. Kosakata berpusat pada bidang-bidang seperti objek-objek dasar, tempat, dan istilah kekerabatan yang paling umum. Pengucapan mungkin masih sangat dipengaruhi oleh bahasa pertama. Kesalahan sering terjadi. Di samping dengan melakukan pengulangan pengucapan, penutur pada tingkat Novice-high akan sulit dipahami bahkan oleh lawan bicara yang memperhatikannya.

3) Pedoman ACTFL: Membaca - Novice 
a) Novice-Low

Sesekali bisa mengidentifikasi kata-kata terisolasi dan/atau frase utama saat didukung oleh konteks yang kuat.

b) Novice-Mid

Mampu mengenali simbol-simbol huruf abjad dan/atau sistem penulisan suku kata dan/atau sejumlah karakter dalam suatu sistem yang menggunakan karakter. Pembaca bisa mengidentifikasi sejumlah peningkatan sejumlah konteks kata dan/atau frasa termasuk cognate (bahasa yang sama asalnya) dan kata-kata pinjaman jika sesuai. Materi yang dipahami jarang melebihi frase tunggal pada satu waktu, dan mungkin diperlukan pengulanagan dalam membaca.

c) Novice-High

Memiliki kontrol yang memadai dari sistem penulisan untuk menafsirkan bahasa tertulis dalam bidang-bidang kebutuhan praktis. Setelah pembaca mempelajari beberapa materi kosakata, mereka bisa membaca untuk tujuan pengarahan dan pembelajaran, pesan standar, frase, atau ekspresi, seperti beberapa pilihan pada menu makanan, jadwal, peta, dan tanda-tanda. Meskipun mereka seringkali tidak konsisten, pembaca pada tingkat Novice-high mungkin bisa memahami makna dari materi yang lebih sulit apabila didukung oleh konteks dan/atau mempunyai latar belakang pengetahuan ekstra linguistik yang bagus.

4) Pedoman ACTFL: Menulis - Novice

a) Novice-Low

Mampu membuat beberapa huruf dalam sebuah sistem abjad. Di dalam bahasa yang tulisannya menggunakan sistem suku kata atau karakter, penulis mampu menyalin dan menghasilkan coretan dasar. Bisa menghasilkan romanisasi karakter tunggal apabila diperlukan.

b) Novice-Mid

Mampu menyalin atau menuliskan katakata atau frasa umum dan memperbanyak beberapa kata atau frase dari memori. Tidak ada kemampuan menulis praktis yang komunikatif. c) Novice-High

Mampu menulis hanya terbatas pada halhal sederhada, ekspresi-ekspresi tetap dan materi dan rekombinasi yang telah dihafalnya. Bisa menyediakan informasi pada dokumen dan bentuk-bentuk yang sederhana. Bisa menulis nama, nomor, tanggal, ekbangsaan sendiri, dna informasi otobiografi sederhana, serta beberapa kalimat sinkat dan daftar sederhana. Bisa menulis semua simbol dalam sistem alfabetis atau suku kata atau 50-100 karakter atau majemuk dalam suatu sistem penulisan karakter. Sebagian besar ejaan dan representasi simbolsimbol (huruf, suku kata, karakter) sudah benar.

Hal-hal yang disa dipahami pada tingkatan Novice, yaitu (1) nama-nama benda; (2) nama-nama makanan dan minuman; (3) katakata untuk tindakan-tindakan umum; (4) salam dan ekspresi-ekspresi yang umum dalam perpisahan; (5) peringatan dan perintah-perintah dasar, seperti Berhenti!, Awas!, dan Hati-hati!; (6) kata-kata dasar yang menggambarkan ukuran, warna, atau usia; dan (7) pertanyaan dan pernyataan sederhana yang menggunakan katakata dari kategori di atas. Kemudian, hal-hal yang bisa dikuasai dalam berbicara pada tingkatan Novice, yaitu (1) menyapa orang dengan sopan; (2) mengucapkan ucapan terima kasih dengan sopan; (3) mengatakan "ya" dan "tidak"; (4) menggunakan frasa yang telah hafal untuk memesan secangkir kopi atau makanan; (5) menghitung sampai 100; (6) mengucapkan selamat tinggal dengan sopan; (7) memberitahukan nama Anda; (8) mengatakan tentang asal-usul dirinya; (9) nama objek-objek konkret, seperti mebel, tanaman, hewan, alatalat, mesin, dan jenis-jenis makanan; (10) nama dari jenis-jenis orang, seperti laki-laki, perempuan, anak laki-laki, gadis, dan bayi; (11) nama warna; dan (12) nama ukuran objek atau umur orang, seperti perahu besar atau anak kecil. Selanjutnya, hal-hal yang bisa dikuasai dalam membaca pada tingkatan Novice, yaitu (1) huruf dalam alphabet atau sistem penulisan suku kata atau beberapa karakter dalam sistem yang menggunakan karakter; (2) menu; (3) jadwal; (4) peta; (5) rambu-rambu jalan; dan (6) tanda-tanda 
di atas toko. Lalu, hal-hal yang bisa dikuasai dalam menulis pada tingkatan Novice; yaitu (1) informasi untuk formulis registrasi hotel; (2) nformasi untuk dokumen perjalanan; (3) ekspresi-ekspresi sederhana; (4) kata atau kalimat yang telah dipelajari; dan (5) tanggal dan nomor.

Pedoman ACTFL menjadi dasar penyusunan silabus dan materi pembelajaran karena di dalam pedoman ACTFL telah dirinci kemampuan pembelajar bahasa asing pada empat aspek keterampilan berbahasa. Selain itu, penyusunan silabus dan materi pembelajaran BIPA untuk tingkat pemula juga didasarkan pada analisis kebutuhan. Tujuan pembelajaran juga sangat menentukan materi yang diajarkan, teks bacaan yang diberikan, teks dialog yang dicontohkan, dan sebagainya.

\section{KESIMPULAN}

Pembelajaran bahasa tidak lepas dari keterampilan berbahasa yang dimiliki seseorang. Seperti pembelajaran bahasa pada umumnya, program BIPA mempunyai empat keterampilan berbahasa dalam pelajarannya yang terdiri atas empat komponen, yaitu (a) keterampilan menyimak atau listening skill, (b) keterampilan berbicara atau speaking skill, (c) keterampulan membaca atau read-ing skill, dan (d) keterampilan menulis atau writing skill. Keterampilan menyimak atau listening skill dan keterampilan membaca atau reading skill termasuk dalam keterampilan reseptif, sedangkan keterampilan berbicara atau speaking skill dan keterampilan menulis atau writing skill termasuk dalam keterampilan produktif. Baik belajar bahasa untuk tujuan khusus (BIPA) maupun belajar bahasa Indonesia untuk tujuan umum, bagi pelajar bahasa Indonesia digunakan sebagai alat. Bahasa Indonesia difungsikan sebagai alat komunikasi baik secara lisan maupun tulis. Oleh karena itu, dalam pembelajaran BIPA, tujuan yang ingin dicapai adalah kemampuan pelajar untuk berkomunikasi dengan menggunakan bahasa Indonesia yang dipelajarinya. Dengan demikian, pelajar diharapkan dapat memiliki kemampuan komunikatif. Berdasarkan alasan tersebutlah, perangkat pembelajaran yang akan dikembangkan hanya fokus pada pembelajaran menulis dan berbicara.
Perangkat pembelajaran yang dikembangkan berpedoman pada korespondensi skala kemahiran American Council for Teaching Foreign Language (ACTFL). Peneliti memilih pedoman American Council for Teaching Foreign Language (ACTFL) karena ada beberapa keunggulan yang dimiliki oleh ACTFL dan tidak dimiliki oleh korespondensi skala kemahiran lain. Salah satu keunggulan ACFTL yang paling menonjol adalah pengklasifikasian kemampuan berbahasa pelajar berdasarkan empat keterampilan berbahasa. Keunggulan ini tidak dimiliki oleh skala korespondensi skala kemahiran berbahasa yang lain, misalnya, The Common European of Reference for Languages (CEFR). Selain itu, pelevelan yang terdapat dalam American Council for Teaching Foreign Language (ACTFL) lebih rinci karena ada 11 level, yaitu native, distinguished, superior, advance plus, advance, intermediate high, intermediate mid, intermediate low, novice high, novice mid, dan novice low. Maka, tujuan dari penelitian ini adalah untuk mendeskripsikan hasil analisis kebutuhan belajar dan disesuaikan dengan pedoman kemahiran berbahasa American Council for Teaching Foreign Language (ACTFL) untuk menyusun perangkat pembelajaran BIPA tingkat pemula.

\section{SARAN}

Berdasarkan rumusan simpulan di atas, saran yang dapat diajukan, yaitu dengan analisis hasil kebutuhan belajar guru dapat memilih dan menyesuaikan materi yang cocok untuk pelajar. Dengan demikian, pembelajaran yang dilaksanakan sesuai dengan tujuan pembelajaran dan akan dapat bermanfaat secara maksimal.

\section{DAFTAR RUJUKAN}

Deneme, S. 2010. Cross-Cultural Differences in Language Learning Strategy Preference: A Comparative Study. The International Journal Language Society and Culture, (Online), 31 (1): 81-89, (www.educ.utas.edu.au/users/tle/ JOURNAL), diakses 1 September 2014. Hasan, M. Z. 1990. Pengembangan Penelitian Kualitatif dalam Bidang Bahasa dan Sastra. Dalam Aminuddin (Eds.), Karakteristik Peniltian Kualitatif (hlm. 12-25). Malang: YA 3. Hymes, D. 1971. On Communicative Competence. Dalam Pride, J.B. dan Holmes, J. 
(Eds), Sosiolinguistics. Middlesex: Penguin Books.

Richard, J.C. 2001. Curriculum Development in Language Teaching. United States of America: Cambridge University Press.
Suyitno, I. 2004. Pengetahuan Dasar BIPA:

Pandangan Teoritis Belajar Bahasa. Yogyakarta: CV. Grafika Indah

Tim ILR. 1986. Skala Korespondensi Kemahiran: American Council for Teaching Foreign Lamguage. USA 
28\| Azza Aulia Ramadhani, Analisis Kebutuhan Belajar ..... 


\title{
STUDENTS' PERCEPTION TOWARD ROLE PLAY ACTIVITY IN THE ESP CLASS ROOM
}

\author{
Endang Setiyo Astuti \\ Program Studi Pendidikan Bahasa Inggris \\ IKIP Budi Utomo Malang \\ mynameisendang@gmail.com
}

\begin{abstract}
Abstrak: Pembelajaran bahasa Inggris yang dikhususkan dalam konteksbidang tertentu dikenal dengan ESP (BahasaInggrisuntuktujuankhusus). Tujuannya adalah untuk mengembangkan potensi linguistic mahasiswa yang membutuhkan pengetahuan bahasa di bidangnya.Sejalan dengan tujuannya, pembelajaran ESP dilakukan dengan mengajarkan keterampilan berbahasa, salah satunya adalah keterampilan berbicara. Penelitian inidilakukan di sebuah Akademi Kebidanan di Malang, yang melaksanakan program ESP bagi mahasiswanya. Dalam proses pembelajarannya, salah satu instruktur menerapkans trategi roleplay karena melihat bahwa strategi ini dapat memotivas imahasiswa untuk aktifberbicara bahasaInggris. Maka, tujuan penelitian ini adalah untuk mendeskripsikan bagaimana kegiatan roleplay dilakukan di kelas ESP dan apa persepsi mahasiswa terhadap kegiatan roleplay. Penelitian ini menggunakan metodedeskriptifkualitatif yang menggunakan angket, interview, dan observasi sebagai instrument untuk mengumpulkan data. .Hasilnya menunjukkan bahwa mahasiswa memiliki persepsi yang positif terhadap kegiatan dalam roleplay karena mereka berkesempatan untuk berlatih berbicara bahasa Inggrisdengan mengalam isituasi yang seolah-olah nyata di dunia kerja sehingga meningkatkan percaya diri mereka.Kegiatan dalam roleplay juga dapat meningkatkan interaksi di antara mahasiswa.
\end{abstract}

Kata kunci :persepsi, role play, ESP

The demand of professionals competent in English is unavoidable nowadays. Hence, people in all disciplines are making such efforts to prepare themselves in the job fields. It is also done by colleges of health services, such as pharmacy, nursing, and mid wifery, in which they oblige the students to take English class. It is specified to the students' need in their area of work or study. The English program is known as English for Specific Purposes (ESP). Hutchinson (1986) defined ESPas a language teaching given to the students who have professional study and job-related reason so that English is used in common context or in the context of the students' subject area. The aim of the ESP program is to develop the linguistic potentialities of the students who need the language to update knowledge in their specialties.Regarding with the purposes of the program, the teaching learning of ESP is also done by teaching the students the language skills. One language skill taught in ESP is speaking skillsince it is essential skill that should be mastered by students.

However, the students face problems in speaking such as difficulty to arrange the sentences, fear of making mistakes, and lack of motivation as Nunan (1992) stated that there are some challenges in teaching speaking skill in English as a Foreign Language (EFL) classroom namely lack of motivation, and they are prone to use their first language. Furthermore, Deller (2007) explains that it is not easy to get students to speak about unfamiliar topics because they need more time to prepare and focus on the content in English.This was also experienced by the ESP lecturer of dr. Soepraoenmidwifery academy in which the students were reluctant to speak English because of the shyness and the fear of making mistakes. The assigned topics which were not related to their area of study often made them in difficulty to speak English.

Related to those problems, an activity that was applied by the lecturer in the ESP classroom was role play, thatis an activity leading the students to play such a drama. The student plays a role to be another person in a certain situation. Such a situation leads the researcher to do this study in which the objective is to know how the role play activity was done in the ESP classroom and what the students' perceptions toward the role play activity are. Ladousse (2009) stated that 
role play is an enjoyable activity and does not threaten the students. So, it is important for the students to practice the speaking skill by pretending to behave in the real situation. Nestel and Tierney (2007) also added that role play is used to acquire knowledge, attitudes, and skills in learners of all ages. It is suitable for the adult students as well to do such activity in the ESP classroom. Besides it can also be done in any discipline of knowledge, as DeNeve and Heppner, (1997) supported that over the years role play has become a teaching technique in many diverse settings and disciplines, such as communications, crosscultural training, industrial psychology, business, management, marketing, economics, law, law enforcement, medicine, political science and sociology. According to Byrne (1986) role play can be grouped into two forms, scripted and unscripted role play. Scripted role play involves interpreting either the textbook dialogue or speaking text in the form of speech. The main function of the text after all is to convey the meaning of language items in a memorably way. In contrast to scripted role play, the situations of unscripted role play do not depend on textbooks. It is known as a free role play or improvisation. The students themselves have to decide what language to use and how the conversation should develop.

Meanwhile, to achieve the purpose of learning English through the role play activity, it is important to know the students' perception toward the activity. Szilagyi and Wallace (1980) defined perception as a process by which individuals attend to incoming stimuli, organize, and then interpret such stimuli into a message that in turn indicates an appropriate action or behavior. Huffman et al (1997) added that perception is the process of selecting, organizing, and interpreting sensory data into usable mental representations of the world. This means that someone can receive something as good or bad perception depends on what they feel in facing the object. So, positive perception on learning activities affects students' behavior to have higher motivation in the learning process.

\section{METHOD}

This research used the descriptive qualitative design. The subject of this research was the students of midwifery academy.The instruments used to collect the data were interview, questionnaire, and observation. The interview was done to get the information from the lecturer about the reason why role play was applied in the ESP class. Questionnaire was distributed to the students of midwifery academy in order to know about their perception toward the role play activity. It used the Likertscale in which the students responded by choosing either Strongly Agree (SA), Agree (A), Disagree (D), or Strongly Disagree (SD) to the ten statements. The observation was done by the researcher to the activity of role play in classroom regarding with the engagement of students in the process of role play activity in the classroom. The participants of this research were 42 female students of midwifery academy. They consisted of 23 students from class A and 19 students from class B.

\section{FINDINGS AND DISCUSSION \\ Questionnaire}

There were ten statements concerning with the perception of the students towards the role play activity in English class needed to respond by the students. The statements were classified into two topics consisted of three statements about the importance of learning English for their future job as midwives and seven statements about the advantages of learning English through role play activity in the classroom (see Appendix). The result is showed in the following table:

\begin{tabular}{|c|l|c|c|c|c|}
\hline No & \multicolumn{1}{|c|}{ Statements } & $\begin{array}{c}\text { Strongly } \\
\text { Agree }\end{array}$ & Agree & Disagree & $\begin{array}{c}\text { Strongly } \\
\text { Disagree }\end{array}$ \\
\hline 1 & $\begin{array}{l}\text { The importance of learning English } \\
\text { for their future job. }\end{array}$ & $15 \%$ & $82 \%$ & $3 \%$ & $0 \%$ \\
\hline 2 & $\begin{array}{l}\text { The advantages learning English } \\
\text { through role play activity. }\end{array}$ & $8 \%$ & $88 \%$ & $2 \%$ & $0 \%$ \\
\hline
\end{tabular}


In general, the average result above showed that more than $90 \%$ students had positive perception toward the role play activity in the ESP classroom. Regarding with the importance of English in their area of study, 15\% students strongly agreed and $82 \%$ students agreed to learn English in the college because it was useful to support their future job while only 3\% students disagreed that English was not important for their future job. The responses concerning with the advantages of role play activity in the ESP classroom showed that $8 \%$ students strongly agreed, $88 \%$ students agreed, and $2 \%$ students disagree.

\section{Interview}

From the interview with the lecturer, it was known that role play was the suitable activity for the students of ESP class because they could practice playing roles as what they would get in the future after graduating from this academy. In terms of the topic assigned to the students, the lecturer said that it should be the familiar one and required their need. Since they were the students of midwifery academy, the roles they played would be as the midwives, the patients or pregnant women with the problems regarding the pregnancy. It was quite relevant with the purpose of this academy that is to prepare them to be skillful midwives. Moreover, the students could practice their speaking skill in this activity, especially the vocabulary and pronunciation. Scripted role play was chosen by the lecturer to do the activity in which the students could firstly write the dialog and discuss it with their partners in group before presenting in front of class.

\section{Observation}

From the observation done by the researcher in two classes $\mathrm{A}$ and $\mathrm{B}$, it was found that the students were ready in experiencing the learning process. Only some students from two groups were not ready in presenting the roles. All the students were cooperative in doing the activity. It was shown by the preparation they had before the presentation. The students cooperated to each other to set the classroom into a clinic-like-room. Besides they also prepared some properties such as a baby doll, stethoscope, blood pressure gauge, thermometer, etc. to support their performance. All the students were responsible with the assigned roles and tried to speak actively although some of them still mixed English with bahasa Indonesia. Some others sometimes looked up the notes when they forgot the dialog. In general, the conversations were understandable. The students looked confident in performing the play. The mistakes made by the students in terms of pronunciation and grammar were not given feedback immediately, but after the performance by the teacher. Most of the plays ran quite well.

\section{CONCLUSION}

Role play activity has positive impact in improving students' speaking skills as it gives the students a chance to explore different situations of real life and enables them to speak English confidently in that situation. Although during role play in a large class room, the situation gets confusing and the performerssometimes forget their dialogues, which create embarrassment, the students usually try to finish the assignment well.Teachers may give immediate verbal feedback or written feedback in case of technical difficulties while recording acts.

\section{REFERENCES}

Byrne, D. 1986. Teaching Oral English: Longman Handbooks for English Teachers. Singapore: Longman Group.

Deller,S. \& Price, C. 2007. Teaching Other Subjects through English. Oxford University Press

DeNeve, K. M. \& Heppner, M. J. 1997. Role Play Simulations: The Assessment of An Active Learning Technique and Comparisons with Traditional Lectures. Innovative HigherEducation, 21(3), 231-246.

Huffman, et al.,1997.Psychology in Action. $4^{\text {th }}$ Edition. Canada: John Wiley \& Sons, Inc.

Hutchinson, T \& Waters, A. 1987.English for Specific Purpose, A Learning Centered Approach. Cambridge: Cambridge University Press.

Ladousse, G. 2009. Role Play.New York: Oxford University press. Littlewood, W. 1981.Communicative Language Teaching. Oxford: Oxford University

Nestel, D. \& Tierney, T.2007.Role-play for Medical Students Learning about Communication: Guidelines for Maximizing Benefits. BioMed Central Medical Education, 1-9. 
32|| Endang Setiyo Astuti, Students' Perception Toward Role .....

Nunan, D. 1992. Research Methods in Language Learning. New York: Cambridge University Press.
Szilagy, Andrew D. et al, 1980. Organizational Behavior and Performances. California: Good Year Publishing Company, Inc. 